IZA DP No. 4692

In School or at Work? Evidence from a Crisis

Florencia López Bóo

January 2010 


\title{
In School or at Work? Evidence from a Crisis
}

\author{
Florencia López Bóo \\ Inter-American Development Bank, \\ University of Oxford and IZA
}

Discussion Paper No. 4692

January 2010

\author{
IZA \\ P.O. Box 7240 \\ 53072 Bonn \\ Germany \\ Phone: +49-228-3894-0 \\ Fax: +49-228-3894-180 \\ E-mail: iza@iza.org
}

Any opinions expressed here are those of the author(s) and not those of IZA. Research published in this series may include views on policy, but the institute itself takes no institutional policy positions.

The Institute for the Study of Labor (IZA) in Bonn is a local and virtual international research center and a place of communication between science, politics and business. IZA is an independent nonprofit organization supported by Deutsche Post Foundation. The center is associated with the University of Bonn and offers a stimulating research environment through its international network, workshops and conferences, data service, project support, research visits and doctoral program. IZA engages in (i) original and internationally competitive research in all fields of labor economics, (ii) development of policy concepts, and (iii) dissemination of research results and concepts to the interested public.

IZA Discussion Papers often represent preliminary work and are circulated to encourage discussion. Citation of such a paper should account for its provisional character. A revised version may be available directly from the author. 
IZA Discussion Paper No. 4692

January 2010

\section{ABSTRACT \\ In School or at Work? Evidence from a Crisis*}

This paper examines the effect of labor market opportunities on schooling-employment decisions in 12 urban areas in Argentina over 12 years, emphasizing the recession/crisis years 1998-2002. The effects of macroeconomic swings on schooling decisions are examined with a focus on whether the income or substitution effect dominates as macroeconomic conditions change. I demonstrate that over "typical" years deteriorating job rates (or wages) increase the probability of attending school and decrease the probability of combining work and school, particularly for boys. After controlling for household and individual characteristics I find that the probability of being in school for secondary school youth was about 6 percentage points higher in 2002 than in 1998 (before the recession started). In fact, a 10 percent decrease in the job rate alone has been responsible for a 5.4 percentage point rise in the probability of school attendance since 2000 . This effect is attenuated during the 2002 crisis when household expectations change in response to shocks. These estimates allow for the fact that a new Federal Education Law (FEL) in 1996 extended mandatory education to 10 years and might have affected schooling outcomes.

JEL Classification: $\quad$ 121, J31

Keywords: $\quad$ schooling decision, macroeconomic shocks, local labor market opportunities

Corresponding author:

Florencia López Bóo

Inter-American Development Bank

1300 New York Ave.

Washington, DC 20577

USA

E-mail: florencial@iadb.org

\footnotetext{
* The author wishes to thank Francis Teal for very helpful discussions. The paper also benefited from comments received from Adrian Wood, Simon Appleton, Stephen Bond, Martin Browning, Oxford University's Gorman and Labour and Applied Microeconometrics, RES/IDB, IEA-2008, NEUDC-2008, LACEA-2008 and IZA Employment and Development 2009 seminars participants. This paper has circulated as "How do crises affect schooling decisions? Evidence from changing labor market opportunities". This document reflects the opinions of the author and does not represent the opinions of the Inter-American Development Bank or its Board of Directors. The usual disclaimer applies.
} 


\section{Introduction}

How might macroeconomic crises impact school enrollment and labor market decisions among the youth in a developing country? In the absence of formal insurance and safety net mechanisms, the ability of families to smooth economic shocks has been of concern to policymakers who wish to minimize the long-term adverse implications of macroeconomic crises and also maintain high levels of human capital.

If children or youth drop out of school and are sent into the labor market in reaction to a fall in household income, the likelihood that they return to school once the economic situation becomes more stable will be relatively small. This can lead to a permanent decline in human capital and (lifetime) earnings, particularly for less privileged youth. ${ }^{1}$ This has been the main hypothesis tested in the literature for developing countries. However, the fact that households may cut back on expenditures on the education of their children during a crisis is plausible but not self-evident (Schady, 2004; Thomas et al, 2004; Beegle et al, 2005a).

Negative macroeconomic shocks might well depress employment and wage projections, and therefore the opportunity cost of going to school will fall. Ceteris paribus, this should lead to increases in investment in human capital. Nevertheless, a shock could also make borrowing constraints more binding and thus decrease the amount of schooling chosen. These crises (if persistent) might also lower expected lifetime earnings, thus changing the marginal benefit of attending school. Additionally, if the earnings of all individuals are reduced by the same share, the marginal benefit of one more year of education should be lower. But crises need not have a homogeneous effect on (expected) earnings. As long as crises change the marginal costs and benefits of schooling, they may also affect their timing; and in particular, the degree to which youth combine school and work. Obviously, the consequence of a crisis on adult or older siblings employment and incomes in the household will affect the schooling-employment decisions of younger children as well.

The total outcome will then depend on the relative size of the changes in the marginal costs and benefits, as well as on the cross-price elasticity of children's employment and adult/older-siblings' wages. Overall, the effect of macroeconomic fluctuations on schooling-employment decisions is uncertain in theory.

Combining these ambiguous results with the implementation of a National Education Policy further complicates the analysis. However, there are econometric techniques that are helpful in analyzing the effects of such policies and disentangling them from other outcomes. These methods exploit the

\footnotetext{
${ }^{1}$ For instance, five years subsequent to an experience of child labor, Beegle et al (2005b) find significant negative effects on school participation and educational attainment, but also find substantially higher earnings for those (young) adults who worked as children.
} 
variation in treatment intensity across different groups to identify the effect of the implementation of a given policy on variables such as school attendance and employment, among others (Card and Krueger 1994, Duflo 2001).

Given such tentative predictions from the theory in terms of the effects of macroeconomic crises on schooling and the lack of systematic analysis of education policies in Latin America, careful country-specific empirical work is needed.

The classic "drop out" story is that decreases in family income led children to work outside the house or to undertake additional domestic tasks so that other household members can participate in the labor market; and this seems to hold for countries like Cote d'Ivoire and Vietnam (Jensen, 2000; Beegle et al 2005a). However, some authors find positive impact on schooling after negative shocks (Goldin 1999, Schady 2004), while others suggest that by large enrollment decisions are unaffected by macroeconomic crises, especially moderate ones (Jacoby and Skoufias, 1997; De Ferranti et al, 2000; Thomas et al, 2004). In sum, the effects of income shocks on schooling seem to vary considerably by country as well as by the nature of the crisis.

For Argentina the scant existing evidence has so far been contradictory. España et al (2003) find that the crises of the late 1990s and early 2000s did not change overall enrollment levels; while Rucci (2004) finds that shocks in Argentina led to declines in schooling over the 1998-2002 recession. ${ }^{2}$ This paper moves away from the focus on the effects of shocks on credit constraints (or income effect) and considers the extent to which fluctuations in local labor markets opportunities and changes in the organization of the education system might also have effects on schooling and employment decisions.

I analyze these two effects with microdata on secondary school-age youth in Argentina in the 1992-2003 period using a multinomial logit to take into account the joint nature of school-employment decisions while controlling for other covariates. ${ }^{3}$

Most of the earlier studies on this topic have focused on the binary

\footnotetext{
${ }^{2}$ I will argue that results have been contradictory for two reasons: first, the chosen sample (i.e. Rucci uses the 12-17 year-olds and España et al use two samples: 6-14 and 18-25 year-olds); while the relevant sample should be the secondary-school aged that are closer to marginal decisions (i.e. 13-18 year-olds); and second, the identification strategy (i.e. Rucci identifies the shocks with the trend of the Brazil-Argentina exchange rate, while España et al do not have a clear identification strategy).

3 Another advantage of the multinomial logit is that it does not impose an arbitrary structure on the outcomes. However, other natural alternatives would be a conditional logit model which requires detailed longitudinal data. Also the multinomial probit model that makes calculation of maximum likelihood infeasible for more than five alternatives as it involves multiple integrals (Wooldridge 2002); and a bivariate probit model which imposes only a four-choice model. The Independence of Irrelevant Alternatives (IIA) hypothesis can also be relaxed by specifying a hierarchical model, ranking the choice alternatives. The most popular of these is called the nested logit model (Hausman and McFadden, 1984). Again the problem is that in the Argentine data there is no information on choice attributes.
} 
choice between school and work or the fourfold choice among school, work, school and work, or neither. Although these studies have provided policy makers with information about the factors influencing schooling and labor decisions of school-age youth, there is more to be learned from a further disaggregated analysis of this choice by also considering unemployed youth (i.e. those seeking work but not working). This is particularly relevant for a high-unemployment country like Argentina, in which the proportion of inactive youth (i.e. no-work no-school) is one of the highest in Latin America reaching about 15 percent of $15-18$ year olds. ${ }^{4}$ An analysis with this level of detail can be undertaken using the data provided by the Encuesta Permanente de Hogares (Argentine Permanent Household Survey, EPH hereafter), which allow me to distinguish between six choices facing school-aged youth: school only, work only, school and work, inactive, unemployed only, school and unemployed. One of the contributions of this paper is that I show that it is not justifiable on statistical grounds to pool any of the six choices.

In terms of the identification strategy, the main difficulty is to find an appropriate proxy for the opportunity cost of youth. Some studies include the child's wage as a proxy, but because not many children work, estimates of children's wages are subject to serious selectivity biases. In Brazil, the effects of local labor market opportunities on schooling have been identified by the variation across states in wage movements (Duryea and Arends Kuenning 2003). However, in Argentina unemployment has been one of the most important results of crises, even though "discouraged worker" effects were also a byproduct of the mid-1990s crises.

For this reason, the identification strategy mainly relies on the variation across urban-areas in job rates, but also unemployment and wage rates of low skilled adults. ${ }^{5}$ The effects of macroeconomic swings on schooling decisions are examined with a focus on whether the income or substitution effect dominates as macroeconomic conditions change. ${ }^{6}$

Lastly, in order to unravel the effect of the new education policy, I make use of the change in the Federal Education Law $(F E L)$ in 1996 in Argentina that extended mandatory education from seven to ten years. This quasiexperiment can be used to disentangle the aggregate labor market effects and the effects of the Law itself both identified at the urban area level. The

\footnotetext{
4 Moreover the inactivity rate kept increasing until 1998, a feature which needs to be taken into account in the econometric model.

${ }^{5}$ Urban-area level wages have not fluctuated as much as urban-area level employment rates before the 2002 crisis; still I show results using wages as a measure of the opportunity cost.

${ }^{6}$ The substitution effect "story" comes from two empirical observations: First, percapita household income decreased by almost 30 percent for all deciles and all levels of education during the $2000 / 2002$ crisis which seems to support a uniform across-the-board decrease in expected earnings. Secondly, the secular increasing trend in the marginal benefits to schooling stopped in 1998, just before the start of the recession in 1999 . It therefore seems unlikely that changes in access to credit or in rates of return to education can explain the patters of attendance in Argentina, at least over the recession crisis period of 1998 to 2002 .
} 
education reform was gradual, in the sense that every year a new province (or set of provinces) adopted the FEL, providing variation that can be exploited in the empirical analysis.

The rest of the paper is structured as follows. The next section shows schooling and employment trends in Argentina from 1992 to 2003, surveys the nature of the crises and also describes the Federal Education Law. Section 2 gives details on the theoretical and econometrical framework of analysis. Section 3 briefly explains the data, while Section 4 describes the empirical strategy. Section 5 presents the results and Section 6 concludes.

\section{Schooling and Employment Trends}

\subsection{Aggregate fluctuations, enrollment and employment}

Before proceeding with the analysis of factors associated with youth educational and employment outcomes I give a brief overview of basic indicators from 1992 to 2003. It is important to highlight that although Argentina is a developing country, the education sector ranks highly in comparison with other countries. Average years of schooling for the population aged 15 and over in 2000 were 8.8, significantly higher than the Latin-American average of 5.9 years. It is important to note that in 2004, 77 percent of students (initial, primary and secondary education) were in public schools. ${ }^{7}$ Moreover, from 1991 to 2001 enrollment growth was 33 percent points higher than population growth for those aged 15-17.

In terms of child labor, the law protects children from exploitation in the workplace and sets the minimum age for employment at 14 years, although in rare cases the Ministry of Education may authorize a younger child to work as part of a family unit. Children between the ages of 14 and 18 may work in a limited number of job categories and for limited hours if they have completed compulsory schooling, which normally ends at age $15 .^{8}$ In 2004 the National Commission for the Eradication of Child Labor (CONAETI) estimated that up to 1.5 million children, or 22 percent of the children under the age of 15 , worked in some capacity. Most illegal child labor took place in the informal sector, where inspectors had limited ability to enforce the law. Child labor in urban zones included work such as smallscale garment production, trash recycling, street sales, domestic service, and food preparation. Children also were involved in prostitution, sex tourism, and drug trafficking.

I present a synopsis of attendance, employment, unemployment and inactivity trends of 5-25 year old in Figures 1 to 3 in the Appendix. Attendance rates rose for all those aged 12-25 from 1992 to 2002, attaining 100 percent

\footnotetext{
7 Therefore, schooling decisions should not be largely affected by fees.

${ }^{8}$ See section 1.2 for more details on Argentina's educational structure.
} 
of attendance for 12-14 year olds by the end of the decade. Those aged 12-18 years had the largest increases in attendance rates.

On the other hand, employment rates went down, this effect being strongest for those aged 15-18 from 1998 onwards. ${ }^{9}$ Figure 2 shows 1217 year-olds combining work and school more in 1992 than in any other year (except for those aged 15) ${ }^{10}$ However, the highest rate of youth combining employment and schooling at age 18 is found in 1999, which coincides with the highest unemployment rate recorded up until that year. On the other hand, the proportion of inactive 5 - 18 year-old went down by 2.5 percentage points from 1992 to 2002. This decline was more pronounced for 12 to 18-year-olds, for whom this proportion decreased by 3.5 percentage points. For those over the age of 16 the inactivity rate goes up over time reaching 20 percent for all those over the age of 20 .

Figure 4 summarizes these information for the population of interest (13-18 year-olds) and shows the prediction for secondary-school attendance based on a linear regression of attendance on time $(t=1,2, \ldots \mathrm{n})$, along with a 95 percent confidence level interval. This is presented by relevant age-group and gender.

Overall, the raw data and the fitted values are compelling evidence pointing towards the fact that the schooling trend before 1997 is clearly different from the trend after 1997. ${ }^{11}$ There are two competing plausible explanations for these trends: the aggregate macroeconomic effects on employment levels and the implementation of a new Federal Education Law extending the number of years that youth have to stay in school. ${ }^{12}$

Argentina suffered two shocks over this period: in 1995, Argentina the shock has been caused by the contagion effect from the Mexican currency crisis. In consequence massive amounts of capital were pulled out of the country, unemployment rose to 18.4 percent and GDP fell by 2.8 percent. In 2002 , the crisis was of a different nature. The Government could not sustain the peg of the national currency (the peso) and was forced to devalue by 40 percent. This devaluation was then followed by a historic debt default, GDP fell by 10.9 percent and unemployment went up to 21.5 percent. As shown in Figure 4, after the 1995 shock there is a negative change in the enrollment rates, particular those of 15-18-year-old females, while after the 2002 shock one can observe that enrollment rates for both genders equally halted the increasing trend in attendance observed from 1997 to 2001 . I describe the Federal Education Law and its plausible effects briefly in the

\footnotetext{
${ }^{9}$ It should be noted that unemployment rates for workers under 20 year old are 3 times higher than the unemployment rates of workers aged 35 and over.

${ }^{10}$ Combining work with school is defined as a dummy equal to one if the $12-17$ year-olds report to be working in the reference week and at the same time report to be attending school.

${ }^{11}$ In despite of the small ' $t$ ' ( $t=12$ ) I also show the Zivot-Andrews (1992) unit root test in Figure 4

12 The fall in employment rates was particularly harsh for 15-18 year olds after 1998
} 
next subsection.

\subsection{The Federal Education Law}

Following the pattern of educational policies in Latin American countries during the 1990s, a new reform programme was launched by the Federal Government resulting in, among other laws: the Federal Education Law in 1993 ( $F E L$ hereafter). Despite the fact that this Law had been already sanctioned, the implementation only began in 1996. The reform was gradual, and from 1996 a different set of provinces implemented the reform each year, until the last of the implementing provinces, Mendoza, applied it in 2000. As of 2003 , however, only 17 out of 24 provinces had carried out the reform completely, and five provinces were still in the phase of pilots programs or partial implementation.

The degree of implementation varied from one province to another. The reforms covered different areas, but I focus on only one: the extension of mandatory education from seven to 10 years. ${ }^{13}$ All students are potentially subject to the effects of $F E L$ and each province decides whether to implement it, as well as whether to engage in generalized or gradual implementation. Inconclusive evidence on the exogeneity of adoption of the Law turns out to be crucial as I explain in the empirical strategy section.

The greatest change in this new organization of education affects youth aged 12 to 14 years through the following areas of curriculum reform: (i) Nine years of General Basic Education- EGB1, EGB2 and EGB3- for 6-14 year old children (now mandatory) and (ii) Three or four years of Polymodal or High School for 15 to 17-18 year olds (not mandatory).

As shown in the first column of Table 1, only two provinces (Buenos Aires and Cordoba) implemented the reform in 1996. At the time this paper was written, only two provinces (Río Negro and Ciudad Autónoma de Buenos Aires) have not applied the reform. However, only a few provinces followed a full implementation policy. ${ }^{14}$ Column (iv) shows the years since the FEL was applied. This variable was constructed based on column (i) and taking as reference the year 2000. Nearly 75 percent of total gross enrollment in secondary school for the year 1996 was in provinces which fully implemented the FEL (column (v)). Buenos Aires province represents 37.3 percent of total enrollment (or 49.5 percent of all students in FEL provinces). I comment more on the last column in Section 3 .

The following sections will explore the extent to which the observed increase in attendance for 13 to 18-year-olds was a consequence of the lack of

\footnotetext{
13 Other areas of reforms were: (i) the transfer of national responsibilities to the provinces for secondary and technical education; and for teacher training institutions, (ii) curricular reform; (iii) administrative reforms and (iv) higher education reform.

${ }^{14}$ This was quite a common strategy with nine provinces beginning with this modality (see column (iii) of Table 1).
} 
employment opportunities, this new Law or a combination of these factors. ${ }^{15}$

\section{Theoretical and Econometric Framework}

\subsection{Theoretical Framework}

Empirical research on schooling investment has been inspired by the standard neoclassical Becker model of human capital accumulation where individuals acquire education until the (expected) marginal benefit of an additional year of education equals the marginal cost (Figure 5. ${ }^{16}$ The underlying assumptions are: complete markets, the only cost of schooling is foregone earnings and fees, youth earn nothing while at school and no value is attached to education as a consumption good (Rosen 1977, Willis 1986). However, in a developing country like Argentina, two features of the schooling decision problem are missing. The first is, additional (i.e. part-time or full time) earnings which may lead to a lower cost of an additional year of education ${ }^{17}$ and the second, incomplete markets and borrowing constraints that may lead to under-investment in human capital (Becker 1964, Galor and Zeira 1993, Jacoby 1994). In a model with altruism (Andreoni 1989), borrowing constraints will then prevent perfect smoothing of consumption, and the outcome will be, if labor displaces schooling (Ravallion and Wodon 2000), underinvestment in human capital as a by product of child/youth labor (Basu and Van 1998).

The marginal private benefit curve depends on the expected private gains (i.e. in wages/salaries in labor markets where, for instance, returns to education and unemployment rates will play a role) to human capital investment. The marginal private cost may increase with human resource investments because of the increasing opportunity costs of more time devoted to such investments and because of increasing marginal private costs of borrowing on financial markets (if such markets do not easily permit borrowing for such purposes, at some point the marginal private cost curve may become very

\footnotetext{
${ }^{15}$ Galiani and Schargrodsky (2001) used a different aspect of the same political experiment. They exploit the generated exogenous variation in the jurisdiction of administration of secondary schools across time and space in order to identify the causal effect of school decentralization on education quality, measured by the outcome of a standardized test of Spanish and Mathematics administered to students in their final year of secondary school. Crosta (2007) evaluates the relationship between the FEL, access to schooling and the quality of schooling. However, he does not use the nationally representative and comparable EPH surveys as he only has the Encuesta de Condiciones de Vida-2001 survey.

${ }^{16}$ As is common in the literature I assume that parents decide investments in education for under-18 year-old.

17 The organization of the secondary school curriculum in Argentina is such that a fulltime job should not be possible to maintain while studying. However, I found that those 13-18 year-olds that report to be employed are working an average of 37 hours/week (vis a vis 44 hours/week for those aged 15-62), which is compatible with the definition of full time job, and therefore seems to indicate that labor is not displacing school, but rather leisure time (Ravallion and Wodon 2000). On the other hand, only 35 percent of those 13-18 year old that are employed work 25 hours/week or less.
} 
steep or even vertical). Moreover, the possibility of working will have two effects: via the income effect it might reduce credit constraints and then decrease the private marginal cost of borrowing on financial markets, therefore leading to a higher investment in human capital. Via the opportunity cost, the substitution effect will in turn decrease investment in human capital.

In this framework researchers have studied the effects of various factors such as household income shocks, returns to education and family background on the marginal costs and benefits of an additional year of education. ${ }^{18}$

There is also considerable evidence of convex rather than concave earningseducation profiles in developing countries (Söderbom et al, 2006), including Argentina (López Bóo, 2008) (Lopez Boo 2008). Therefore an individual needs to complete a considerable number of years of schooling in order to reap substantial gains from her investment. Consequently, a large education budget may be necessary if schooling is evaluated as a human capital investment, and one would therefore expect household income to matter in a very direct way when evaluating educational outcomes. Unsurprisingly, the developing country literature has found a systematic relationship between educational outcomes and family income (Behrman and Knowles 1999). The positive impact of income is also used by many as evidence of binding credit constraints in developing countries.

In this paper I move away from credit constraints and the traditional determinants of schooling-employment decisions to concentrate on the effects of macroeconomic crises controlling by the implementation of the FEL, and explore whether income or substitution effects dominate with aggregate changes in local labor market opportunities.

\subsection{Econometric Approach: Multinomial Logit Models for School-Employment Decisions}

I employ a reduced-form production function to examine the effect of aggregate changes in labor market conditions and the FEL on attendancework decisions of school-aged youth. This can be performed by means of a multinomial logit if one wants to take into account the joint nature of school-labor decisions while controlling for other covariates. The multinomial logit specification is attractive in applied work, due to its simplicity, at the cost of parametric and (testable) independence assumptions. ${ }^{19}$ For in-

\footnotetext{
18 It is well-known that variables like the occupation of the mother and the father, parental education (usually a proxy for permanent income) and the mother being in the labor force are strong predictors of schooling levels in Latin America. Sometimes these variables are even more important determinants of educational attaintment that household income is (Hausmann and Szekely 2001, Behrman, Birdsall, and Szekely 2000). This seems to be the case for the Greater Buenos Aires (GBA) (Sosa and Marchionni 1999).

19 The multinomial logit clearly suffers of a serious shortcoming when analyzing the secondary-school aged labor market, because it assumes the hypothesis of independence of irrelevant alternatives (IIA hypothesis). In this context, this would imply that labour
} 
stance, if students with a high graduation probability decide to go to school and those with a low probability decide to work (and not attend school), then the multinomial logit would not be the correct model. Evidence for Argentina admits, however, that this ordering may not be appropriate, particularly when considering the choice between school and work (Sosa and Marchionni 1999). If there is no clear ordering then the multinomial logit model is the preferred specification since it does not impose an arbitrary structure on the outcomes (Long 1997).

Most of the earlier studies have focused either on the binary choice between school and work (de Janvry et al, 2006) ; while some consider the four-fold choice between school only, work only, school and work, or neither (Duryea and Arends Kuenning 2003). Although these studies have provided policy makers with crucial information about the factors influencing schoollabor decisions of school-age youth, there is more to be learned by further disaggregation. This can be done using the data provided by EPH, which allow me to distinguish between six choices facing secondary school-aged youth: school only, work only, unemployed only, school and work, school and unemployed and inactive. Ideally, I should estimate a nested logit model or a random parameters logit model, which are plausibly a more appropriate specification. ${ }^{20}{ }^{21}$ However, due to data limitations (i.e. no information on choice-specific attributes) I am unable to estimate such models. However, I show by means of Hausman-type test of the independence of irrelevant alternatives (IIA) that it is not justifiable on statistical grounds to pool any of the six choices. ${ }^{22}$

I model the schooling-employment decision following the literature on occupational choice, using a latent variable approach. The latent variable is the propensity to sort into a given activity. Only the outcome and not the underlying propensity is actually observed:

$$
y_{j}^{*}=Z \gamma_{j}+\eta_{j}
$$

Depending on whether one conditions on "some activity" I can have

market choices be independent from education. I explain how I deal with this in Section 2.4

The nested logit model is a generalization of the multinomial logit model that allows error terms to be correlated across alternatives within a subgroup of choices. The nesting structure would have asumed that the error terms of the schooling choice (in this case are school only, school and work and school and unemployment) are correlated as so are the errors terms of the no-schooling choice. On the other hand, the random parameters logit (also called 'mixed logit' when the log-normal rather than the normal distribution is used for parameters whose sign is known a priori) also permit the utilities of each alternative to be correlated.

${ }^{21}$ The multinomial probit has been rarely used in this context as it is more challenging to estimate for more than four choices. I have estimated multinomial probits as a robustness check and the main results remain unaltered (these are available upon request).

${ }^{22}$ However, in order to take into account small sample sizes when splitting age groups I pool some categories (i.e. unemployed and employed are pooled as active) in some regressions, while those in school and reporting to be unemployed (very small number of observations per year) will be merged onto the "school only" category. 
three or four $j$ categories. If I condition on activity then the three activities are: only studying $(s)$, only working $(l)$ and combining work with school $(c)$. In the empirical model I also use a classification with five activities (adding the inactive and the unemployed category to the above classification). ${ }^{23}$ However the key points can be made across these three activities outcomes (a). The outcome variable $y_{j}{ }^{*}$ is observed if and only if category $j$ is chosen which happens when

$$
y_{a}^{*}>\max \left(y_{j}^{*}\right)
$$

The key assumptions that underlie the model concern the determinants of the propensity to "sort" into a given activity $a$ (the observables in $Z$ and the unobservables, $\eta_{j}$ ).

This paper focuses on the unbiased estimation of labor market effects also controlling by the implementation of the $F E L$ in times of changes. For this reason, I go into the details of the specification, the variables of interest, controls and identification issues of both labor market effects and the FEL in Section 4 .

\subsection{Hypothesis Testing}

Within this framework, one could expect to test at least four hypotheses (or questions) on schooling-employment decisions for school-aged youth. I am most interested in the first three, while the last serves as robustness tests: First, does human capital investment go up because fewer jobs are available (substitution effect). This can be tested with a set of urban-area labor market variables that will act as a measure of the opportunity cost of staying in school.

Second, does human capital investment go down during crises because fewer jobs and/or depressed wages are available to those who would have liked to combine work and school (income effect). Here the same labor markets variables will be interpreted differently depending on the sign of the coefficient and on the activity category. For instance, job rates are expected to have a positive impact on those youth combining school and work because it increases the probability of funding their studies.

Thirdly, might human capital also go up due to the "illegality" of not being in school arising from the Federal Education Law $(F E L)$. I should be able to identify this effect by performing a before and after $F E L$ comparison for each group of provinces that implemented the Law in different years. That is, I look at 13-18-year-olds in provinces $j$ at $t-1$ and at $t$ and in subsequent years ( $t$ being the year when the $F E L$ is implemented). ${ }^{24}$

\footnotetext{
${ }^{23}$ The inactivity rate increased until 1998 and then fell until 2002, which can potentially matter for selection issues.

${ }^{24}$ Given that there are still time-varying factors that are unobserved for the researcher, I do not claim to be identifying a causal effect, but rather controlling by this effect.
} 
Fourthly, human capital investment might also go down during crises if school-aged youth have to take jobs because crisis/unemployment has affected some jobs more than others (e.g. parents/older siblings lose their jobs) and their households are unable to smooth consumption, then this will increase their marginal cost of attending school, leading to a slower (if school is combined with work) or lower investment (if drop-out occurs) in human capital (income effect). To test this, I use the same labor market variables but split by age groups. I expect the unemployment rate at the urban-area level of adults and older siblings to have a negative effect on enrollment, and a positive effect on the probability of working. ${ }^{25}$

For each one of the hypotheses above I perform the analysis by gender, as outcomes are suspected to be different for girls and boys for two reasons: the acceptability of child labor and the employment opportunities may differ by genders. ${ }^{26}$

\subsection{Testing IIA}

Hausman and McFadden (1984) proposed a Hausman-type of the IIA property. A Hausman test is based on the comparison of two estimators of the same parameters. One estimator is consistent and efficient if the null hypothesis is true, while the second estimator is consistent but inefficient.

Therefore Hausman and McFadden (1978) suggest that if a subset of the choices truly is irrelevant with respect to the other alternatives, omitting it from the model will not lead to inconsistent estimates. Therefore, Hausman's (1978) specification test can be used to test for IIA.

\section{Data and Sample}

\subsection{Data}

All of the following regressions are estimated using all available individual and household level observations from the 1992-2003 May rounds of the Encuesta Permanente de Hogares or Argentine Permanent Household Survey (EPH hereafter). The survey is conducted twice per year (May and October) in urban areas by the Instituto Nacional de Estadisticas y Censos (INDEC).

\footnotetext{
${ }^{25}$ Human capital might also go up due to incentives arising from the increasing returns to college over this period, which have increased dramatically in Argentina over the last 15 years (See Fiszbein et al (2005) and L'pez Bóo, 2008). To test this effect I use wages (both for the unskilled and the skilled) as a measure of the opportunity cost.

${ }^{26}$ Marchionni and Sosa Escudero (1998) found that drop-out rates were higher for boys than for girls aged 13-19 in the Greater Buenos Aires. Rucci (2004) also finds that 12-17 year-old males were more likely to drop out of school during the 1998-2002 Argentine crises, while 12-17 year-old girls were not as likely to do so. For instance, the types of jobs available for 13-18-year-olds in Argentina seem to be better suited to boys than to girls (e.g. cardboard collection, car window cleaning and other informal street jobs). Unfortunately, if girls are working at home, this is not going to be recorded in the household surveys.
} 
The sampling is a two-stage random sample. In a first stage, census areas are chosen with proportional probability according to their size. These primary units are stratified according to the heads education. In a second stage, households are chosen using a systematic sampling method. The survey is designed as a rotating panel. Each household appears in four consecutive waves and after that, it is removed to be replaced with a new household. Therefore, in principle, I could construct a two-year panel. However, attrition is a major problem and I therefore treat the data as repeated cross sections. ${ }^{27}$

As the last available year (2003) only has comparable data available for the May wave, I have decided to take only May waves for all calculations. ${ }^{28}$ This implies that only 13 out of 31 urban areas were left, with these urban areas surveyed for all Mays between 1992 and 2003. I include previous years in despite of the fact that I am missing several urban areas (either because those were not surveyed or because relevant information, such as identification of different sources of earnings, was missing before 1996) because I want to analyze year-to year variation and compare the results from the 2002 shock with those from the 1995 shock. I have an average of 5,200 13-18 year olds per wave, per year.

\subsection{Sample}

For the analysis of school-employment decisions across urban areas I take the sample of secondary school-aged youth in the cross section (e.g. I compare 13-18 year olds in 1992, with 13-18 year olds in 1997, and so forth) that have already completed mandatory primary school ( 85 percent of the sample of this cohort for all years). This is the group that is closest to marginal decisions in terms of schooling-employment for various reasons: first, almost all 5-12 year olds are attending school by the end of the period under analysis as shown in Figure 1. In fact, 96 percent of 12-14 year olds were already attending school in 1997 (the year before the recession began). The sample of youth between the ages of 14 and 18 is then particularly interesting as they work in a limited number of job categories and for limited hours. The Ministry of Education claims that this group can only work if they have completed compulsory schooling, which normally ends at age 15 (since the $F E L$ in 1997; before then compulsory schooling ended at age 12). ${ }^{29}$

\footnotetext{
27 Each panel therefore will have $25 \%$ of the population of a wave (i.e. As $25 \%$ of the sample 'leaves' in each wave, then after two years only $25 \%$ of the original sample is left). However, less than a half of that original $25 \%$ is present. The crisis does not seem to increase the attrition relative to previous waves. I also tried to use short panels as McKenzie (McKenzie 2003) but the attrition was even worse for the 13-18 year-olds that conform my sample

${ }^{28}$ Given that surveys cover only urban areas, most statistics are not significantly affected by seasonality issues.

29 Before the reform, the minimum age required to start high school was 13 years as of the 30 th of June of the entry year. With this reference, an 18-year old student will be in
} 


\subsection{Descriptive statistics}

Tables 2 present additional basic statistics of the variables used in the analysis for the sample of 61,672 urban 13-18 year olds. Years of education of the household head in our sample increased by almost 1 year from 1992 to 2002, while per capita household income went down by almost 50 percent over the whole period. The participation in terms of population of urban areas has stayed fairly constant, while the unemployment rate has tripled, from 6.6 percent in 1992 to 20.4 in 2002 (average being 12.8 percent).

On the other hand, 54 percent of the youth in the sample end up in an urban area (province) that has fully implemented the $F E L$, but it represents 62 per cent of total enrollment for 13-18 year olds as shown in the last column of Table 1. That column shows more explicitly whether a province is available in the dataset for every year. I have then comparable data from 1992 to 2003 for 10 out of 24 provinces (or 7 out of 17 that fully implemented the Law).

I show the trends of the 5 possible states: school only, work only, school and work, inactive and unemployed only in Table 3 . On average, around six percent of the adolescents are reported to be working, 7.3 inactive and 78.8 percent of children are in school.

\section{Empirical and Identification Strategy}

As follows from Section 2.2, I estimate two equations: first, a by-year equation; and second, a pooled equation:

$$
y_{i a k t}=\alpha U_{k t}+\beta F E L_{k t}+\gamma Z_{i a k t}+\eta_{a}+\nu_{i a k t}
$$

Following the literature on education and labor supply decisions, the determinants of the propensity of a young adult $i$ to sort into a given activity $a$ in urban area $k$ at time $t, y_{i a k t}$, will depend on: $Z$, a matrix of observable controls at the young adult (or household) level, with plausible determinants of expected earnings, schooling participation and the reservation wage as independent variables; $U$, a set of urban area variables and $F E L$ the binary variable that takes the value 1 for individuals that reside in urban area $k$ that have completely implemented the FEL in a given year. That is, in 1997 this dummy will capture only those youth living in the two provinces that have implemented the Law (vis-à-vis the provinces that did not implement the Law), while in 1999 it will capture those living in the four provinces that implemented the Law between 1996 and 1998. ${ }^{30}$

\footnotetext{
the last year of high school.

30 The Statistics Institute surveys urban areas within provinces, so I actually have 12 urban areas distributed in 8 provinces. Accordingly, standard errors are always clustered at the urban area level.
} 
In the pooled data version below, $\delta_{k}$ is the urban area fixed effect and $\zeta_{t}$ is the intercept in period $t$ (the period effect), and standard errors are always clustered at the urban area level. If the variation in wages/employment is reduced by including the full set of year dummies, the remaining variation is not enough to identify a significant effect of the urban area wage/employment on schooling and employment outcomes. To solve this I include a crisis year dummy instead of year dummies.

$$
y_{i a k t}=\alpha U_{k t}+\beta F E L_{k t}+\gamma Z_{i a k t}+\delta_{k}+\zeta_{t}+\eta_{a}+\nu_{i a k t}
$$

Thus the empirical strategy consists of the following steps: Firstly, I estimate the determinants of the schooling-work decision which was at the core of the theoretical and econometric model, distinguishing between people that are: only in school, only employed (any type: i.e. self, salaried formal or informal, in the public or private sector), both attending school and employed, unemployed and inactive. This schooling-employment choice is modelled using a multinomial logit. ${ }^{31}{ }^{32}$ In $\mathrm{Z}$ I have age dummies and a male dummy to take account of the fact that how close a child is to marginal schooling decisions and his gender will make a difference in the decision to continue with school or to drop out. $Z$ also includes a vector of household/family characteristics that may determine the reservation wage and parental decisions regarding human capital investment of youth, including the education level of the head of the household as a control for permanent income, household size as a measure of the "quality-quantity trade off" (i.e. whether larger households do not send their offspring to school as much as smaller households, given that I already have a control for per capita income), and the log of per-capita income of the household (excluding youth's earnings). ${ }^{33}$ Household income matters for at least two reasons. First, the convexity in the earnings-education profile makes a large budget necessary when considering education as an investment. Second, it serves as a control for transitory income effects. Education of the spouse and other adults in the household will also be included as controls. These variables will determine the sorting decisions.

Secondly, I add urban-area level labor market variables $(U)$ to identify the effects of local labor market conditions, which I argue identify the shock much better than, for instance, the trend of the Brazil-Argentina exchange rate as used in a previous study by Rucci (2003). This follows the existing literature on the effects of economic shocks and changing local labor market conditions on schooling and employment (Beegle et al, 2005a; Duryea et al,

\footnotetext{
${ }^{31}$ In principle, and for simplification I pool both full time and part time work, but I split these two as a robustness check (results are available upon request).

${ }^{32}$ In theory, the variables in $\mathrm{Z}$ might differ for each alternative (only employment, only school, etc) but I simplify this for now.

${ }^{33}$ I consider youth as secondary workers; in other words, child labor or schooling decisions are made after the income of the household adults has been determined.
} 
2007; de Janvry et al, 2006). These variables serve to test for the hypotheses I presented in Section 2.3. I exploit the variation in labor market variables over time and across urban areas in Argentina as a way of testing the "pull" effect from different opportunities in distinct regional labor markets and see whether this effect holds over crises.

For this purpose I include the following measures: (i) Job rates: number of employed unskilled 18-62 year-old adults (i.e. less than 12 years of education) divided by the total 18-62 year-old population in urban area $k$ as another measure of the opportunity cost of attending school; (ii) Unemployment rates: number of unemployed unskilled 18-62 year-olds divided by the labor force (i.e. 18-62 year-old actively looking for work) ${ }^{34}$. This variable serves to test for "additional worker" effects as well; (iii) Wages of low-skilled workers: average wage of those unskilled workers aged 30-35 in urban area $k .^{35}$

My main measure of the opportunity cost is then the job rate at the urban-area level because the number of jobs available is a better indicator than employment rates per se for labor market shocks in Argentina given the persistence of the "discouraged worker" effect. This is measure is represented in Figure 6

Thirdly, to control for the effect of the Federal Education Law (over and above labor market effects at the urban area level), I add the dummy $F E L$ (constructed from column (ii) of Table 1) in the years when the FEL was adopted in a particular set of provinces $(F E L=1$ if individual $i$ is in province $j$ where the Federal Education Law was fully implemented in year $t$ ).

Following Card and Krueger (1994) and Duflo (2001), I exploit the variation in "treatment" intensity induced by the timing of the programme across regions and cohorts to control for the effect of the implementation of the Law on school attendance and employment. This relies on a 'pseudo' differencesin-differences strategy. I condition on urban area fixed effects when using pooled data and I use a before-and-after comparison (when using by-year regressions). ${ }^{36} 37$

In all the tables, the estimated coefficients of the multinomial logits reflect the effect of each explanatory variable on the likelihood of becoming either: student only, employed only, student and employed, unemployed or idle.

Lastly, as a robustness check I consider age groups $(13 / 14,15 / 16,17 / 18)$

\footnotetext{
${ }^{34} \mathrm{I}$ also used the unemployment rate by skill level and age group and this did not change the main results

${ }^{35}$ This is the wage rate that youth would expect if they decide to enter the labor force. I also used the wage of those 18-62 and results did not change.

${ }^{36}$ In pooled regressions I identify variation in local labor market conditions effects from the variation in employment within each urban area.

${ }^{37}$ In the by-year regressions inclusion of urban fixed effects would not allow the identification of neither the labor market opportunities or the Federal Education Law at the urban-area level.
} 
separately because different factors (including returns to education, family background and other labor market conditions) may have differential effects depending on how close a child is to marginal schooling decisions. A further advantage of considering the age groups separately is that this lessens the risk of biases due to more able youth progressing more in school (i.e. school continuation selectivity on the basis of unobserved ability). ${ }^{38}$

\section{Results}

\subsection{Determinants of schooling-employment decisions: trends and determinants}

Figure 7 provides a graphical representation of the estimates from the multinomial logit in Table 4 (basic specification). The y-axis shows the predicted probability of ending up in each category restricted for an individual 13-18 year old and a given education level of the head of household (as a proxy of parental background), holding all other youth characteristics constant at the sample means. The $\mathrm{x}$-axis shows the number of years of education. These probabilities sum to one for all education groups. I estimate this by gender for 1992, 1996, 1998 and 2002, and I consider the correlation between education and the predicted probabilities of entering each activity.

The predicted probability of school only increases rapidly with years of education of the head of household both for males and females as shown by the slope of the green area in the figure. While the predicted probabilities of work only (red area), combining work and school (light grey area), unemployment (dark grey area), and inactivity (black area); all decrease with increasing years of education of the household head. The decreasing size of the red, light and dark grey areas shows that the probability of working (either combining it with school or not) and unemployment decreases substantially over time, and it is always substantially lower for females. From 1992 until 2001 the probability of inactivity increases sharply for both genders, but this tendency reverses in 2002. ${ }^{39}$

The main contrast between males and females appears appears in the inactivity category. Females whose parent had less than completed primary school (seven years of education) have a much higher predicted probability of being neither at school, nor in the labor force. It is only when the parent has 10 years of education or more than the predicted probabilities start to look more alike between males and females. Still the probability of combining

\footnotetext{
${ }^{38}$ Cameron and Heckman (1998) for instance claim that most of the literature on the effects of parental background on children's attaintment concludes that the effect of family background declines after secondary schooling but that these estimates suffer from omitted ability bias because more able children normally progress more in the education system.

${ }^{39}$ There is an extensive literature on the the "discouraged worker" effect affecting inactivity levels in Argentina (Altimir and Beccaria 2001)
} 
work and school is much higher for males, even those with highly educated parents.

The marginal effects for the basic specification are shown in Table 4 for 13-18 year olds by selected years. Age dummies, gender and householdlevel variables have the expected sign and do not change substantially across specifications.

As expected, attendance is a decreasing function of age (not reported). This is particularly evident for the 18-year olds who have a 60 percent lower predicted probability of attending school only and a higher predicted probability of either combining work with school (10 percent) or only working (50 percent) than a 13 year-old. The (negative) marginal effect of the male dummy decreases over time (from 2 to 0 percent), particularly after 1998, showing a smaller gap between males and females in attendance and a quite stable predominance of young males in the labor force (there is a positive and significant sign of around 2 percent of the male dummy in the only work, work and school and unemployed categories that fades away in 2002).

The importance of the years of schooling of the head of the household decreases over time, in particular from 1998 for all categories. This may reflect the declining importance of "permanent income". Moreover, this variable is not significant for those combining work with school. The household size estimate reflects the same decreasing trend. The relationship between the size of the household and the probability of ending up in school (working) is negative (positive) and significant, supporting the presence of a 'quantityquality' trade-off in household decisions in Argentina.

\subsection{The effect of local labor market opportunities on schooling- employment decisions}

As a preview of results, Figure 8 shows the age range that is closer to marginal decisions and for the sake of clarity I only show males in 1992 (baseline), 1996 (year after 1995 crisis) and 2002 (year after 2001 crisis). It is very clear from this picture that attendance (green area) has increased from 1992 to 2002, while the probability of either working (with or without combining it with school), being unemployed or inactive has shrunk over this 10-year period.

On the other hand, the trend from 1992 to 1996 shows an important increase in unemployment, inactivity and the combination of work with school at the expense of an important decrease in the rate of $15-18$ year-olds working (red area), on average.

Moreover, the decline in schooling attendance in 1996 was not evenly distributed across groups. Children with highly educated heads actually increased their probability of attendance, while youths with less educated heads reduced their probability of attendance and also of work, while they increased their probability of either unemployment or inactivity. In 2002, 
the increase in schooling was more evenly distributed across groups, even if those youths with less educated heads still have higher probabilities of work, unemployment and inactivity than those with highly educated heads. ${ }^{40}$

In Table 4 I include household and child characteristics thought to influence the supply of child labor and schooling, and therefore controlled as much as possible by labor supply shifters. I now test whether urban areas variables (after controlling by the $F E L$ ) remain significant if included in this specification. If the relationship between child labor and urban labor markets is entirely due to variation in labor supply, and the additional controls adequately capture this variation, then the urban area variables should no longer be significant.

Pool regression In Table 6 I pool boys and girls across the 10 years and include as explanatory variables the log of income received by adults in the household as well as the log of wages and the job rates for the low-skilled in the appropriate urban area and year.

I show five specifications: column (1) is the baseline without any labor market variable; in column (2) the log of wages of unskilled workers is added along its interaction with the dummy of crisis year, while column (3) only takes out the income variables. Column (4) and (5) replicate columns (2) and (3) but use job rate instead of low wages as a measure of the opportunity cost. To test whether household behavior changes during an economic crisis, the urban area wage/job rate is interacted with a dummy variable representing the crises years of 1995 and 2002. These are selected as the crisis years in the analysis because GDP per capita was at its lowest levels.

The probability of attending school is lower for boys and lower for older children while these factors increase the probability of working. The education of the household head, is positively and significantly associated with an increased probability of attending school and a decreased probability of working, combining work with school or being unemployed. The proxy for transitory household income, the log of income received by adults in the household, is also associated with a significant increase in the probability of attending school and a significant decrease in the probability of working, combining work with school and unemployment.

An increase in the urban area average wage of less skilled in column (2) is associated with a significant decrease in the probability of attending school (6 percent), suggesting that opportunity costs draw youth away from secondary school. The same happens in column (4) with the job rates measures, even if the size of the effect is much smaller. The significantly higher probability of working with respect to a higher urban area level wage (or employment) confirms that for Argentina, the labor market is contending for youths' time. While the effect of transitory household income is not found

\footnotetext{
${ }^{40}$ Average predicted probabilities for the 13-18 year-olds are shown in Table 5
} 
to be significantly different during the crisis years (same result as Duryea and Kuenning, 2003) the substitution effect as measured by the urban area wage is significantly smaller in magnitude (the interaction is positive in columns 2 and 3 ). This suggests that opportunity costs of the labor market provide an important countervailing effect during "normal" economic downturns (1995) but that this effect is attenuated during a crisis when families expectations change in response to a deep shock. However, the interaction of job rates and crisis years is negative in columns 4 and 5 (but very small and non-significant). ${ }^{41}$

Regressions in columns (2) and (4) show the net effect of the change in labor market conditions after controlling for income at the household level. This approach is the appropriate one for identifying the income and substitution effects. Still one may speculate which effect dominates in a downturn. Regressions in columns (3) and (5) then drops the family income such that the parameter of the urban area-level wage in column (3) or job rates in column (5) measure the overall effect on youth behavior of a labor market downturn. Schooling over periods of "typical" fluctuations is slightly counter-cyclical with children shifting from work to school as labor market conditions deteriorate (either wages or employment). Again the significantly different coefficient of urban area wages (columns 2 and 3) during Argentina's worst years suggests that the typical relationship between youth' time use and macroeconomic conditions does not necessarily hold during a crisis. One again this interaction term during crisis is very small and non-significant when using the job rates variables, which indicates that the counter-cyclical behavior in schooling remains in place. I now go and explore further this last relationship in by-year regressions.

By-year regressions In order to see annual changes I estimate by-year regressions. The preferred specification in Table $7 \mathrm{I}$ test whether labor market variables, a proxy for opportunity costs, have (i) any effect over schooling-employment decisions and (ii) whether those effects vary during crises.

Job rates have the expected sign for all categories (negative for the only school and positive for all others). However, the exception is the crisis year of 2002. Another important point to note is that even if the job rate actually experienced by youth is lower than the unskilled adult rate, differences across urban areas and over time are likely to be similar for the youth rate and the unskilled adult rate as they are moved by the same macroeconomic conditions.

For non-crisis years, the opportunity cost draws youth away from school as shown in the first panel of both tables and also in the coefficient for those

\footnotetext{
${ }^{41}$ By adding dummy variables for each urban area, I identify local market condition effects off of the variation in wages/employment within each urban area.
} 
working or searching for a job in the second to fourth panel. In a crisis year like such as 2002 the substitution effect behaves differently: the effect of the job rate on schooling is positive and significant in Table 7.42

For the first category (only school), the largest coefficient on job rates is for 1994 (1.23 percent), a high employment year, while the lowest marginal effect is found in 2002, a very low employment rate year (0.5 percent). For the second category (only work), it is interesting to note that the estimate on job rates (even if small) is negative in 2002, perhaps reflecting some nonlinearities of the effect of jobs rates below a threshold level. Also, the effect on those combining work and school in 2002 (0.02 percent) is about one tenth the size in 2000 (0.1 percent), which again reflects the diminishing importance of labor market variables in the schooling-employment decision.

In Table 8, unemployment rates, in turn, are partly measuring opportunity cost but also act as a control for the increases in inactivity rates fueled by the high unemployment rates in Argentina over the mid-1990s. They also serve to measure the extent of the "additional worker" effect over crises.

Unemployment is indeed positively and significantly correlated with inactivity in the fifth panel until 1998 when the correlation becomes negative but is insignificant afterwards. On the other hand, the relationship between unemployment and the probability of combining work and school or only working (second and third panels in the table) is an interesting example of how this relationship might change with the macroeconomic environment. For both categories the estimate is positive, but it becomes much smaller in 2002, while is not significant for the working only category. Moreover, unemployment is negatively correlated with the probability of working in all years, except in the two post-crisis years of 1996 and 2002, when that relationship is positive, which could be interpreted as the confirmation of "additional worker" effects happening after crises.

I have replicated the above analysis for various sub-samples: the 13/14 year-olds separated from the 15/16-year-olds and the 17/18-year-olds. Results show that different age cohorts behave systematically differently, namely in that older cohorts (15 to 18 year-olds) are much more sensitive to changes in the labor market variables (results are not reported but available upon request). Probably one of the reasons why previous studies have found contradictory results is because they failed to control for these age-effects and to consider the appropriate sample (secondary school youth).

I also replicated my preferred specification by gender: the "2002 result" still holds (i.e. the coefficient of job rates on the likelihood of being in school

\footnotetext{
${ }^{42}$ Age dummies and gender and household variables do not change in size or magnitude when including urban area variables. I have also included unemployment rates in this same regression and results are available upon request.
} 
switches sign from negative to positive). However, in general, labor market variables despite having the expected sign, show larger coefficients for boys than for girls, which is perhaps the reflection of different attitudes by parents towards boys versus girls in terms of employment. For instance, from 1992 to 2001 (before the crisis), an increase of 10 percent in the job rates will decrease schooling by 6 percent for boys and only by 3 percent for girls.

Another gender difference is the effect of temporary income shocks: household (per capita) income has a large effect on attendance for girls in 2002, while it is not significant for boys. Income decreases the probability of being only working for girls in 2002, but it does not seem to affect it for boys. Results are not reported but are available upon request. ${ }^{43}$

As another robustness test (not reported) I included in the regressions a dummy indicating whether the school attended was private of public as a proxy for the quality of school (this information is only available after 1995), and again results remain unaltered.

Lastly, Table 9, presents different scenarios (i.e. marginal effects) based on Table 7 for three baseline years: one non-crisis year (1992), one start-ofcrisis year along with the end of implementation of the Federal Education Law (2000), and a crisis year (2002). These are estimates that come from changes in either the $F E L$ or from the job rate.

I demonstrate with this summary table that in "typical" years deteriorating job rates increase the probability of attending school and decrease the probability of combining work and school. After controlling for household and individual characteristics a 10 percent decrease in the job rate alone has been responsible for a 5.4 percent rise in the probability of school attendance since 2000 (0.054 in Table 9). This substitution effect becomes positive in 2002 (-0.046 in the same Table). These estimates account for the fact that a new Federal Education Law $(F E L)$ in 1996 extended mandatory education to 10 years and might have affected schooling outcomes. Differences across regions in implementation and differences in exposure across cohorts induced by the timing of the Law allow me to show that youth in provinces fully implementing the FEL in 2000 (when the last set of provinces implemented the Law) were only 3 percentage points more likely to be in school and 1.6 percentage points less likely to be working in $1998 .{ }^{44}$

\footnotetext{
${ }^{43}$ Figure 8 also showed that the probability of being inactive is positively related to being female regardless of the macroeconomic conditions. This may be an indication that labor market variables do not have any pull effect on them, and that more structural variables are behind female-labor decisions.

${ }^{44}$ Still when I compute the probability conditional on the number of years since the implementation of $F E L$, that increase in the "intensity" (i.e. higher exposure to the Law) does not imply an increase in the probability of being only in school (not reported).
} 


\section{Conclusions}

This paper examines the patterns of investment in human capital over the 1992-2003 period for secondary-school aged youth in Argentina covering the profound economic crisis of the 1998-2002 period. The main finding is that households were reluctant to reduce human capital investment and there is no evidence of a drop in school attendance. Indeed, the probability of being in school (and not working) increased by 6 percentage points over the crisis period. This increase was at the expense of being inactive (-2.5 percentage points), combining work and school (-1.9 percentage points) and only working (-1.6 percentage points). During the 2002 crisis, youth were almost 1.8 percentage points less likely to combine work with school than in 1998, and 3 percentage points less likely than in 1994 (a high employment year). This first result suggests that macroeconomic crises do not always slow human capital accumulation. I argue that previous results have been contradictory for two reasons: first, the chosen sample and second, the identification strategy. None of the existing papers used the secondary-school aged youth, which is the relevant age range. Besides, there has not been a clear identification strategy for the shock, while wages, employment and unemployment are the best indicators of macroeconomic conditions in Argentina.

I was able to disentangle the aggregate labor market effects of the crisis and those of the FEL itself, both identified at the urban area level, on schooling decisions. I used adult unskilled (less than 12 years of education) job rates, unemployment and wages to identify the effect of fluctuating labor markets and a dummy ( $=1$ if child $i$ is in a province that has fully implemented the Federal Education Law) to control by this new Education Policy.

Overall, I found that the pull effect from labor markets has been much larger in high employment years than in low employment years and it has almost disappeared in 2002 (in both pool and by-year regressions; and with any of the opportunity cost proxies).

However (and despite the smaller marginal effects on schooling decisions) absolute changes in employment from 1998 to 2002 has been strong enough to provoke increasing attendance rates in this period. This suggests that opportunity costs of the labor market provide an important countervailing effect during "typical" economic downturns (1993-2001) but that this effect is attenuated during a crisis when household expectations change in response to a shock (2002).

The actual 6 percentage point decrease in the average job rate from 1998 to 2002 in Argentina seems to have increased the proportion of youth in school by 3 percentage points (evaluated at the 2000 coefficient), or half 
of the total observed increase in attendance. ${ }^{45} 46$ Boys are more affected by labor market variables than girls which might be related to households' views on work and/or different job opportunities for boys versus girls.

There are two major policy implications: first, given the discrepancy in findings reported in the literature, further research is needed to understand which macroeconomic crises do lead to a slow down in schooling and which do not. Second, where aggregate fluctuations in income do not seem to worsen schooling outcomes, it might be more sensible to establish policies to protect the quality of education (i.e. repetition, test scores, etc.), consumption and health rather than focus on reducing schooling drop-out rates.

\footnotetext{
${ }^{45}$ The job rate went down from 54 percent in 1998 to 48 percent in 2002 (or 6 percentage points)

46 At the same time, by May 2000 the Federal Education Law increased attendance rates by 3 percentage points in those provinces implementing the Law compared to those not implementing it. As FEL provinces are 54 percent of the sample, this implies a total increase in attendance of 1.6 percentage points (.54 times .03).
} 


\section{Appendix}

Definitions of variables in regressions

Dependent variable in equations: Schooling decision $=1$ if attending school only, $=2$ if working only, $=3$ if working and in school, $=4$ if unemployed only, $=5$ if inactive (i.e. no work, no school, no looking for a job).

Age dummies: Built based on the continuous variable age in years (i.e. age 13, ..age18)

Male dummy: $=1$ if male, 0 otherwise

Household Head's Schooling years : Years of education completed (computed at average of educational category for period 1992-1994)

Household size number of individuals in the household.

Log per-capita household income (excluding child earnings) (logpchhy) Log of per-capita real household income (at 1998 prices) excluding the earnings of all those less than 18 year-old in the household.

Job rate (urban-area level) Number of adult individuals unskilled (less than 12 years schooling) employed, divided by the total of 18-62 year old in the urban area, regardless of their activity condition.

Unemployment (urban-area level) Number of adult unemployed individuals unskilled (less than 12 years schooling) divided by the labor force (i.e 18-62-year-olds reporting that they are actively looking for a job in the reference week).

Log wage (urban area) Log of wages of young (30-35 year-olds) unskilled workers (less than 12 years schooling) in the urban area

Treatment dummy (Federal Education Law) $=1$ if individual $i$ is in province $j$ where the Federal Education Law was fully implemented in year $t$.

Crisis year $=1$ if year $=1995$ or 2002 


\section{Figures}

Figure 1: Schooling Attendance (top) and Employment Rate (bottom), by Age
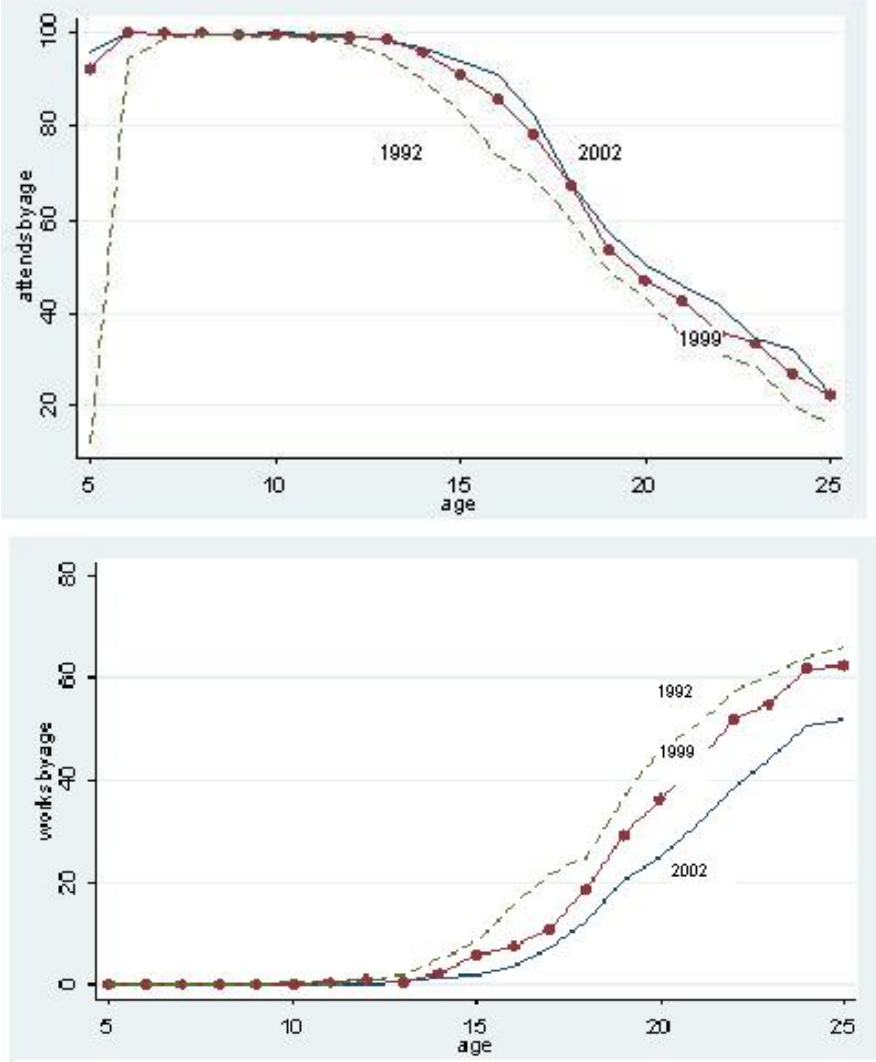

Source: Author's calculations, EPH, Argentina. May waves, 5-25 year-old, 1992, 1999 and 2002. 
Figure 2: Combining School and Work (top) and Unemployment rate (bottom), by Age
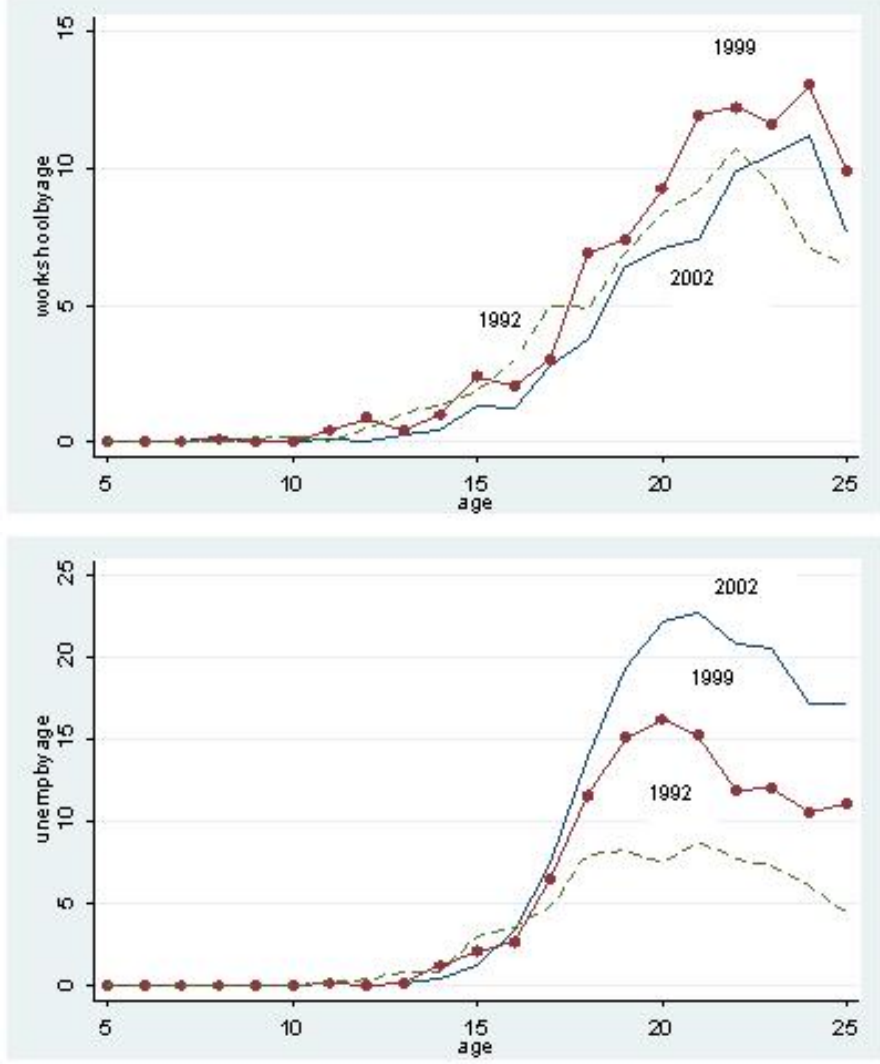

Source: Author's calculations, EPH, Argentina. May waves, 5-25 year-old, 1992, 1999 and 2002. 
Figure 3: Inactive, by age

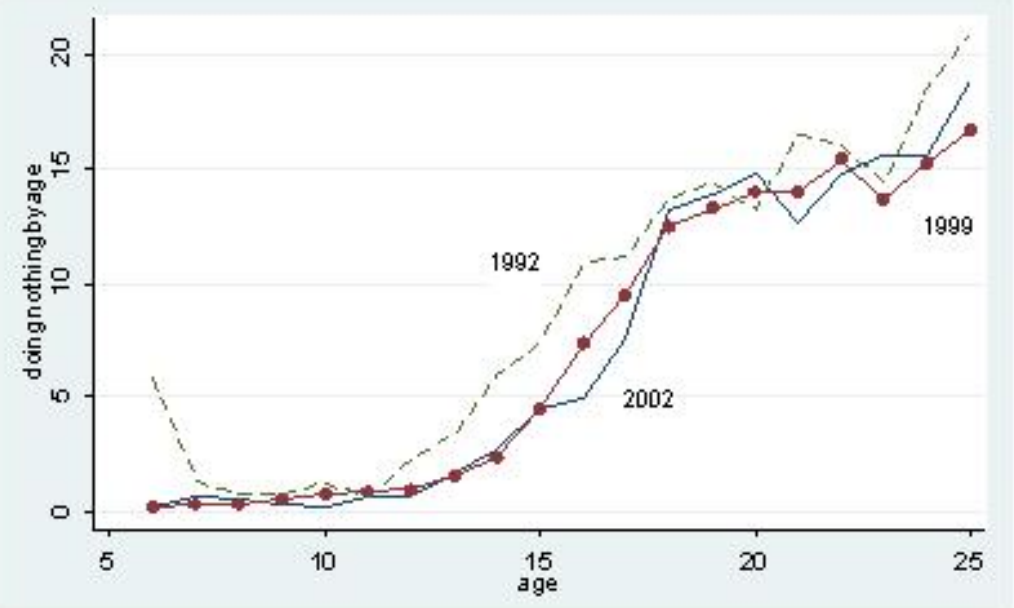

Source:Author's calculations, EPH, Argentina. May waves, 5-25 year-old, 1992, 1999 and 2002. 
Figure 4: Schooling attendance, by secondary school age groups and gender. 13-14 year-olds (top) and 15-18 year-olds (bottom): 1992-2003
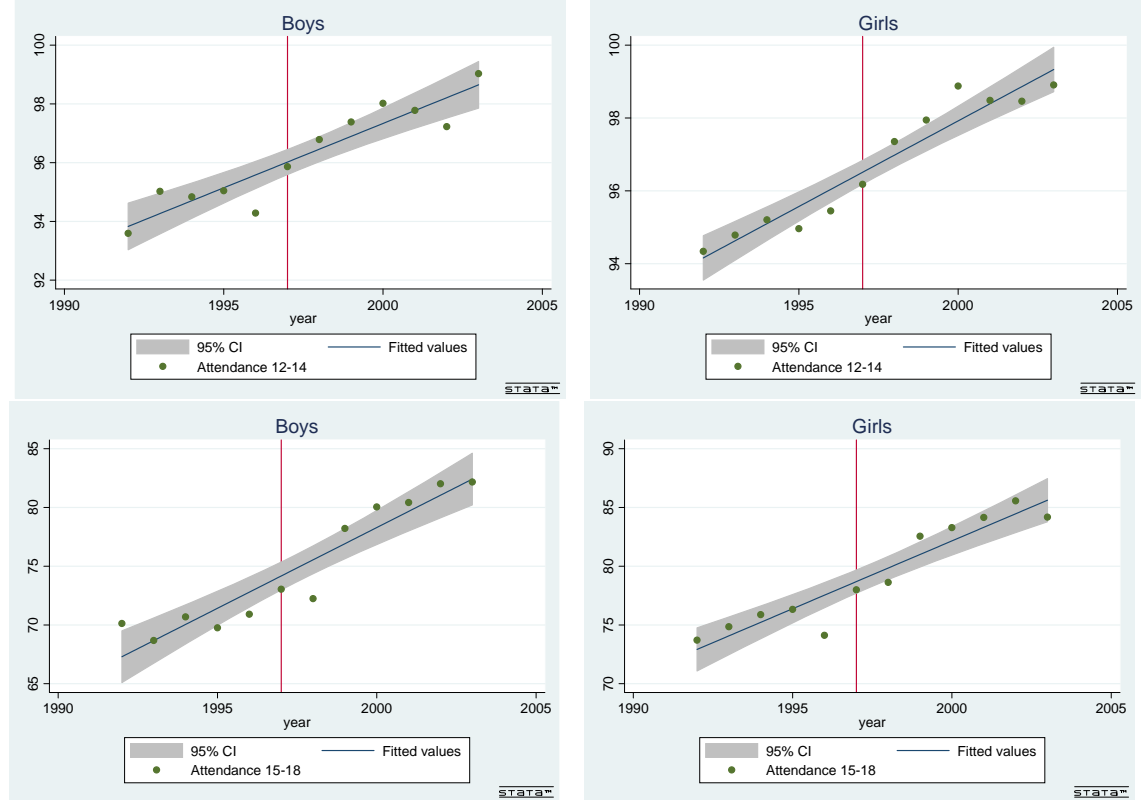

Source: Author's calculations based on Argentina EPH, May waves. Note: The red line shows the presence of a structural break in the attendance trend as per the Zivot-Andrews (1992) unit root test.

Figure 5: Private marginal benefits and private marginal costs of human capital investments

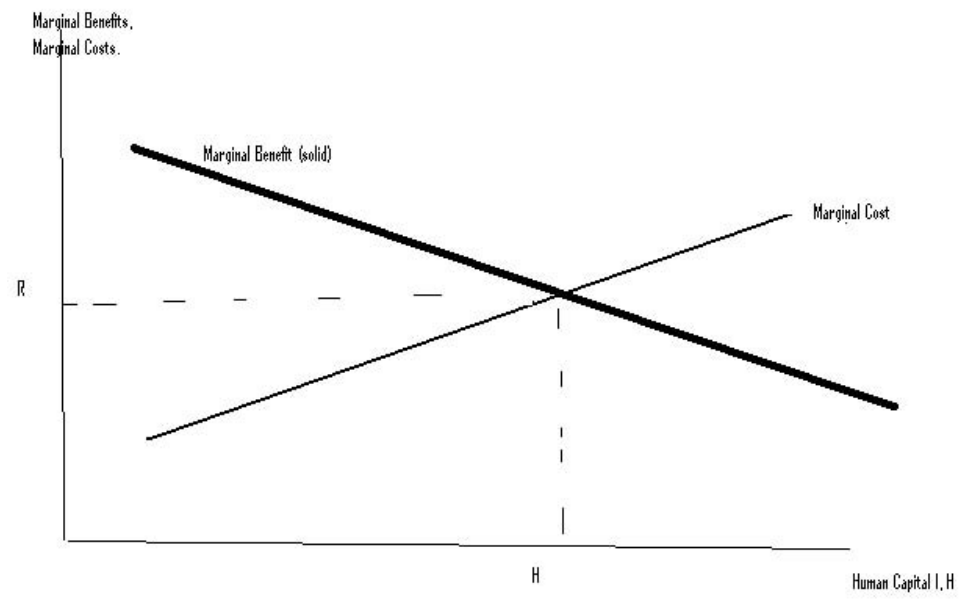


Figure 6: Job rates of unskilled adults 18-62 year of age in selected urban areas.

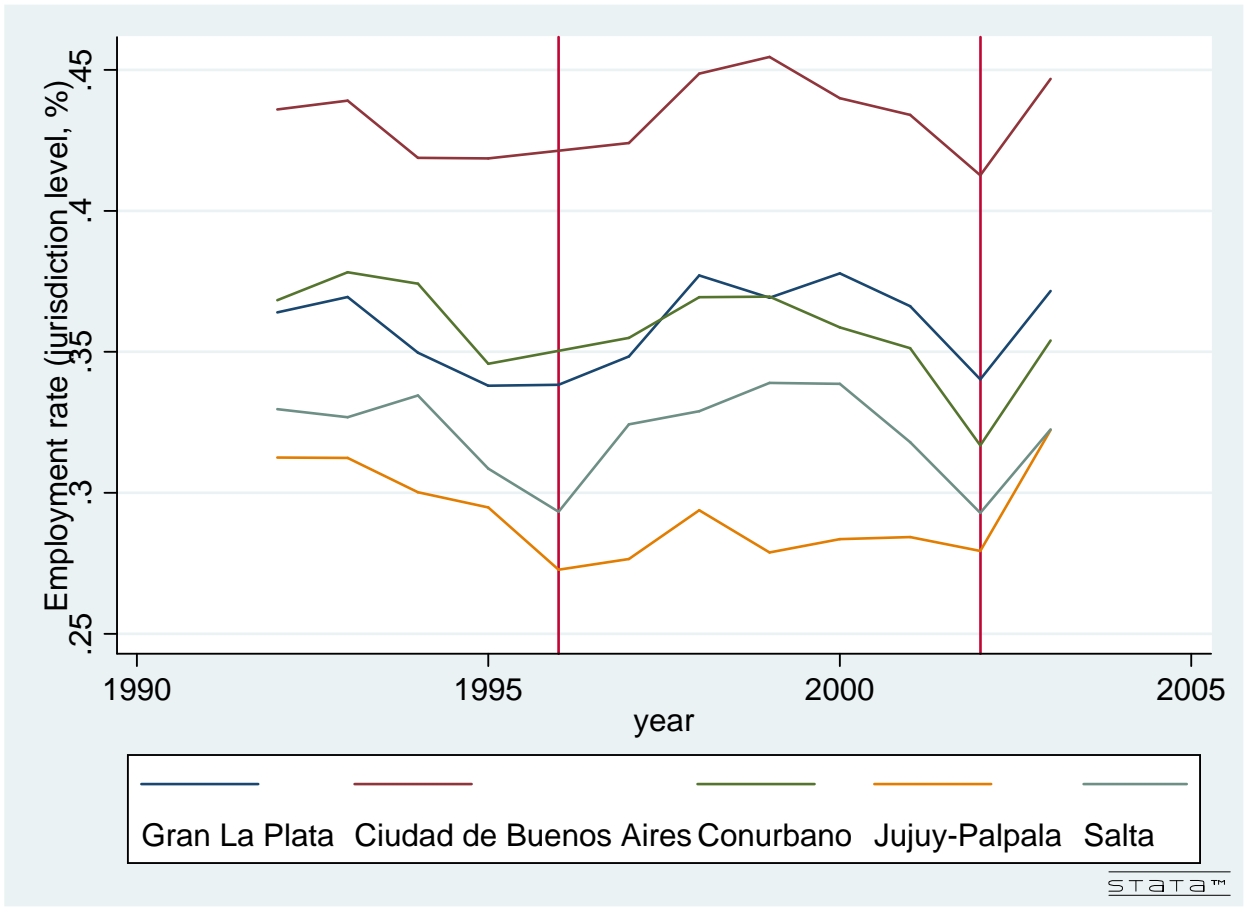

Source: Author's calculations, EPH, Permanent Household Surveys Argentina. May waves 
Figure 7: Predicted Choice by Education Level of Household Head, Holding Other Characteristics at the Mean. Males and females 13-18 years old: 1992, 1996, 1998 and 2002

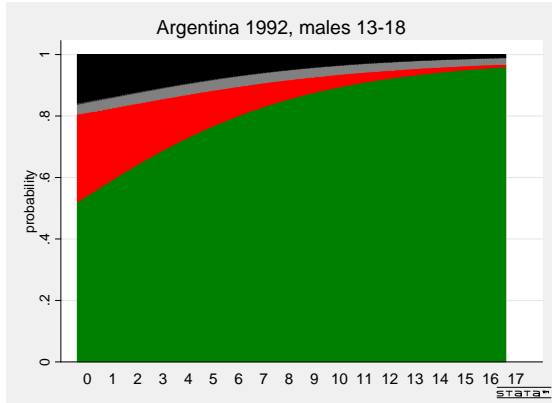

Argentina 1996, males 13-18

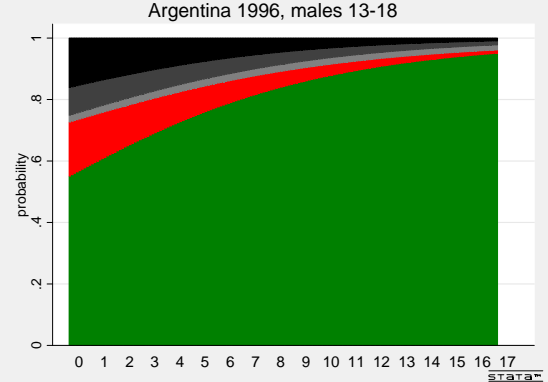

Argentina 1998, males 13-18

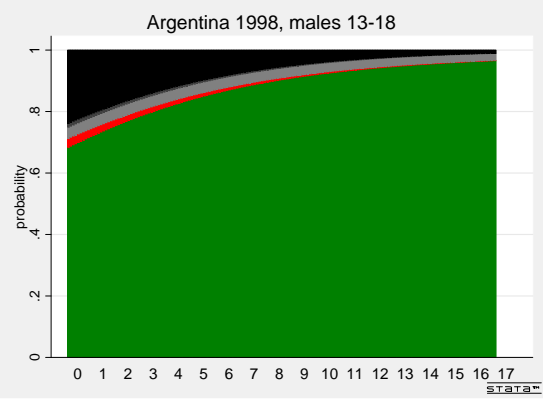

Argentina 2002, males 13-18

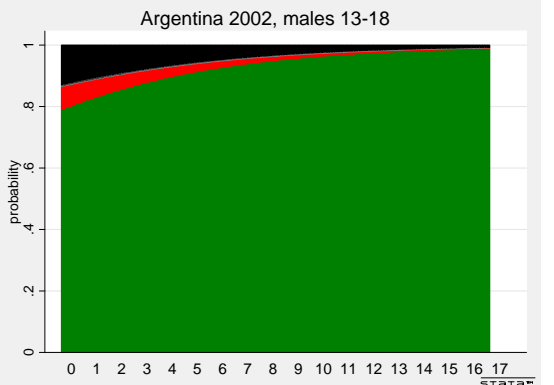

Argentina 1992, females $13-18$

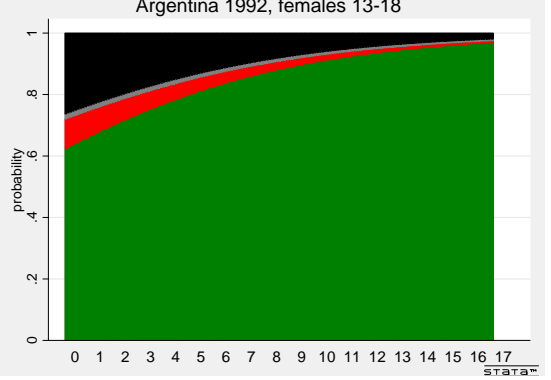

Argentina 1996, females 13-18

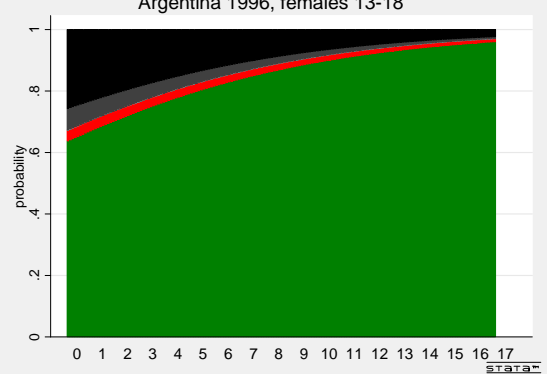

Argentina 1998, females 13-18

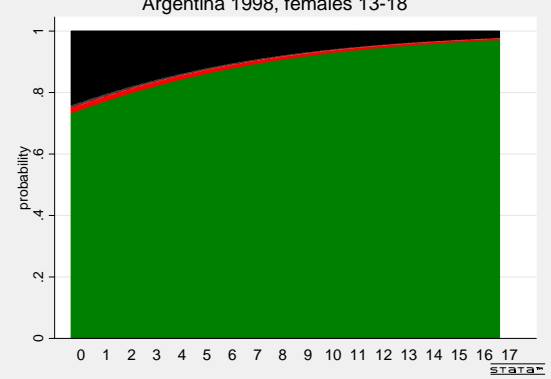

Argentina 2002, females $13-18$

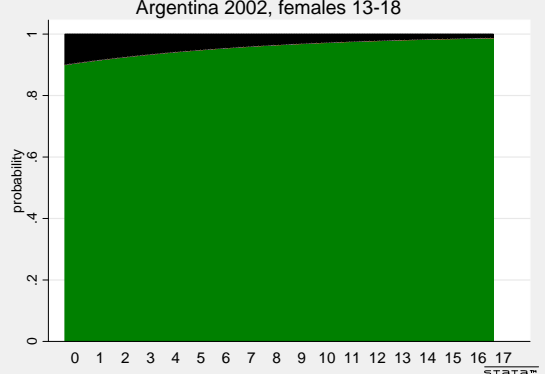

years of schooling $\mathrm{HH}$ head

\begin{tabular}{|l|l|}
\hline Only attending school & Only working \\
Attending school and working & Unemployed \\
Doing nothing & \\
\hline
\end{tabular}

Source: Author's calculations based on Argentina's EPH, May waves. Predicted probabilities after MNL estimationgip Table 4 
Figure 8: Predicted Choice by Education Level of Household Head, Holding Other Characteristics at the Mean. Males 15-18 years old: 1992, 1996 and 2002
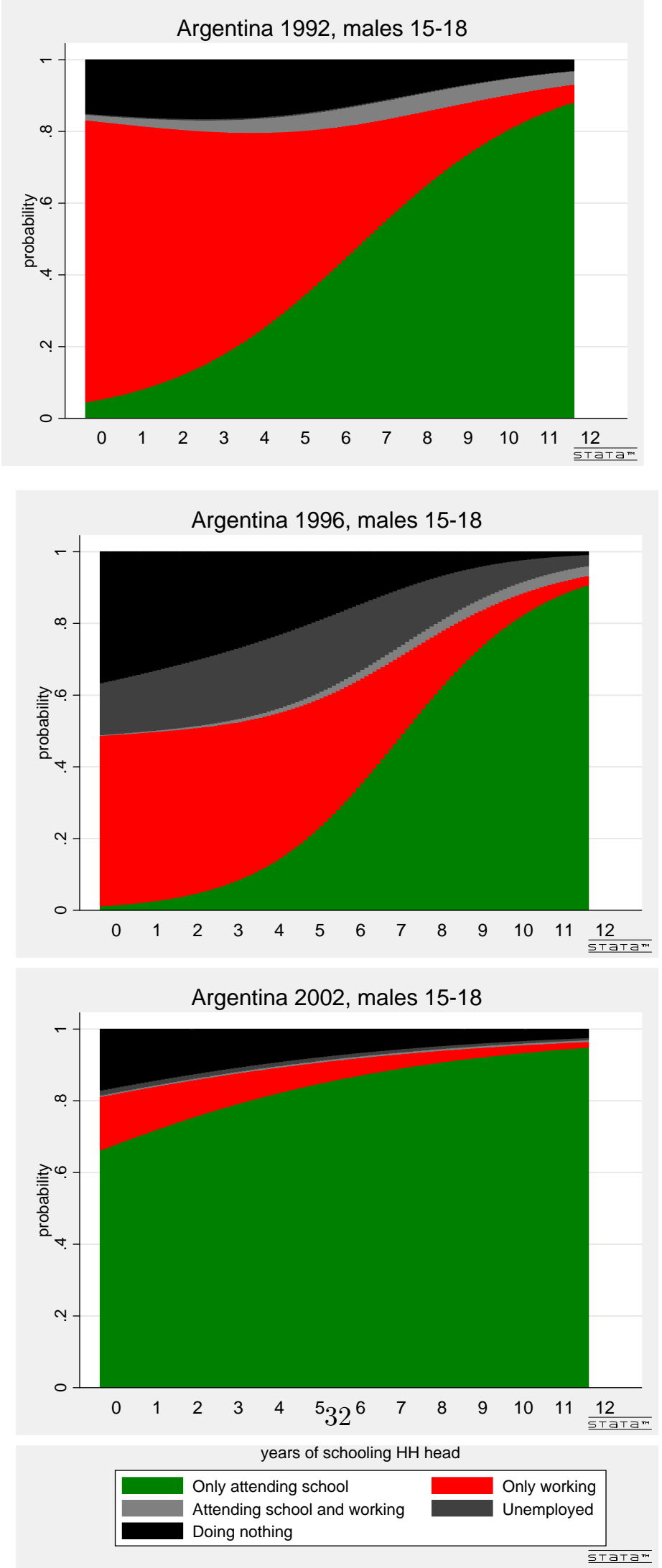
9 Tables 
Table 1: The process of the Federal Education Law (FEL) implementation in Argentina's provinces.

\begin{tabular}{|c|c|c|c|c|c|c|c|}
\hline & \multicolumn{4}{|c|}{ Implementation } & Enrolment & \multicolumn{2}{|c|}{ Available data } \\
\hline & $\begin{array}{l}\text { Year } \\
\text { (i) }\end{array}$ & $\begin{array}{l}\text { Full } \\
\text { (ii) }\end{array}$ & $\begin{array}{l}\text { Mode } \\
\text { (iii) }\end{array}$ & $\begin{array}{l}\text { Years }\left(^{*}\right) \\
\text { (iv) }\end{array}$ & $\begin{array}{c}\% 1996 \\
(\mathrm{v})\end{array}$ & $\begin{array}{c}1992 / 2002 \\
\text { (vi) }\end{array}$ & $\begin{array}{c}1996 \& 2001 \\
\text { (vii) }\end{array}$ \\
\hline CABA $(* *)$ & & No & No & 0 & 9.02 & Yes & Yes \\
\hline Buenos Aires & 1996 & Yes & $\mathrm{U}$ & 5 & 37.28 & Yes & Yes \\
\hline Catamarca & 1999 & Yes & $\mathrm{P}$ & 2 & 0.95 & No & Yes \\
\hline Cordoba & 1996 & Yes & $\mathrm{U}$ & 5 & 8.82 & Yes & Yes \\
\hline Corrientes & 1997 & Yes & $\mathrm{U}$ & 4 & 2.42 & No & Yes \\
\hline Chaco & 1997 & No & $\mathrm{P}$ & 0 & 2.53 & No & Yes \\
\hline Chubut & 1999 & Yes & $\mathrm{P}$ & 2 & 1.29 & Yes & Yes \\
\hline Entre Rios & 1997 & Yes & $\mathrm{U}$ & 4 & 3.16 & Yes & Yes \\
\hline Formosa & 1998 & Yes & $\mathrm{U}$ & 3 & 1.29 & No & Yes \\
\hline Jujuy & 1998 & No & $\mathrm{P}$ & 0 & 2.19 & Yes & Yes \\
\hline La Pampa & 1997 & Yes & $\mathrm{U}$ & 4 & 0.74 & Yes & Yes \\
\hline La Rioja & 1999 & Yes & $\mathrm{P}$ & 2 & 0.80 & No & Yes \\
\hline Mendoza & 2000 & No & $\mathrm{P}$ & 0 & 4.17 & No & Yes \\
\hline Misiones & 1998 & Yes & $\mathrm{U}$ & 3 & 2.14 & No & Yes \\
\hline Neuquén & 1998 & No & $\mathrm{P}$ & 0 & 1.51 & Yes & Yes \\
\hline Río Negro & & No & No & 0 & 1.60 & No & Yes \\
\hline Salta & 1998 & No & $\mathrm{P}$ & 0 & 3.59 & Yes & Yes \\
\hline San Juan & 1997 & Yes & $\mathrm{U}$ & 4 & 1.61 & No & Yes \\
\hline San Luis & 1998 & Yes & $\mathrm{U}$ & 3 & 0.94 & Yes & Yes \\
\hline Santa Cruz & 1998 & Yes & $\mathrm{U}$ & 3 & 0.60 & Yes & Yes \\
\hline Santa Fe & 1997 & Yes & $\mathrm{U}$ & 4 & 8.08 & No & Yes \\
\hline Stg del Estero & 1998 & Yes & $\mathrm{U}$ & 3 & 1.80 & No & Yes \\
\hline Tucumán & 1998 & Yes & $\mathrm{U}$ & 3 & 3.19 & $\mathrm{No}$ & Yes \\
\hline Tierra del Fuego & 1998 & Yes & $\mathrm{P}$ & 3 & 0.29 & No & Yes \\
\hline$\%$ students covered & & & & & & $62 \%$ & $100 \%$ \\
\hline
\end{tabular}

Source: Author's calculations, EPH, Permanent Household Surveys Argentina, May waves; Education Ministry (www.me.gov.ar/cgecse/index.html) and (Crosta 2007). Note 1: In mode of implementation in (column (iii): $\mathrm{No}=$ No implementation, $\mathrm{U}=$ generalized implementation, $\mathrm{P}=$ gradual implementation. Note $2:\left(^{*}\right)$ Years since implementation are measured at 2000. (**) Ciudad Autónoma de Buenos Aires. 


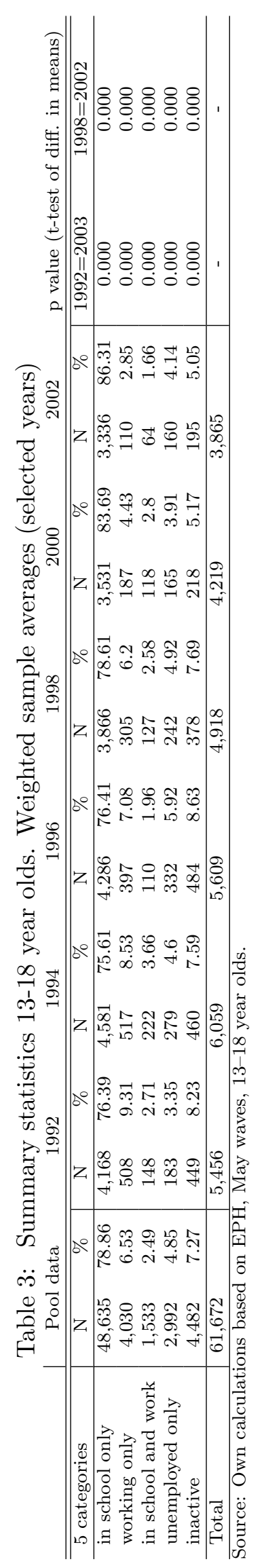


Table 4: Marginal effects, School-Employment choice, 13-18 year olds

\begin{tabular}{|c|c|c|c|c|c|c|}
\hline & $\begin{array}{c}(1) \\
1992\end{array}$ & $\begin{array}{c}(2) \\
1994\end{array}$ & $\begin{array}{c}(3) \\
1996\end{array}$ & $\begin{array}{c}(4) \\
1998\end{array}$ & $\begin{array}{c}(5) \\
2000\end{array}$ & $\begin{array}{c}(6) \\
2002\end{array}$ \\
\hline $\begin{array}{l}\text { 1_-Attending_school_only } \\
\text { male }\end{array}$ & $\begin{array}{c}-0.0220^{*} \\
(-2.37)\end{array}$ & $\begin{array}{c}-0.0428^{* * *} \\
(-4.30)\end{array}$ & $\begin{array}{c}-0.0248^{* *} \\
(-2.59)\end{array}$ & $\begin{array}{c}-0.0305^{* * *} \\
(-3.36)\end{array}$ & $\begin{array}{c}-0.0155^{*} \\
(-2.13)\end{array}$ & $\begin{array}{c}-0.00106 \\
(-0.21)\end{array}$ \\
\hline Householdhead's schooling years & $\begin{array}{c}0.0177^{* * *} \\
(12.30)\end{array}$ & $\begin{array}{l}0.0145^{* * *} \\
(10.40)\end{array}$ & $\begin{array}{c}0.0168^{* * *} \\
(11.62)\end{array}$ & $\begin{array}{l}0.0117^{* * *} \\
(8.94)\end{array}$ & $\begin{array}{l}0.00747^{* * *} \\
(6.37)\end{array}$ & $\begin{array}{l}0.00566^{* * *} \\
(6.14)\end{array}$ \\
\hline Household size & $\begin{array}{c}-0.0125^{* * *} \\
(-5.22)\end{array}$ & $\begin{array}{c}-0.0174^{* * *} \\
(-6.83)\end{array}$ & $\begin{array}{c}-0.0137^{* * *} \\
(-5.61)\end{array}$ & $\begin{array}{c}-0.00966^{* * *} \\
(-4.53)\end{array}$ & $\begin{array}{c}-0.00479^{* *} \\
(-2.74)\end{array}$ & $\begin{array}{c}-0.00341^{*} \\
(-2.55)\end{array}$ \\
\hline logpchhy & $\begin{array}{c}0.0561^{* * *} \\
(6.35)\end{array}$ & $\begin{array}{c}0.0889^{* * *} \\
(9.78)\end{array}$ & $\begin{array}{c}0.0754^{* * *} \\
(8.95)\end{array}$ & $\begin{array}{c}0.0326^{* * *} \\
(5.05)\end{array}$ & $\begin{array}{c}0.0349^{* * *} \\
(5.94)\end{array}$ & $\begin{array}{c}0.0184^{* * *} \\
(4.54)\end{array}$ \\
\hline $\begin{array}{l}\text { 2_-Working_only } \\
\text { male }\end{array}$ & $\begin{array}{c}0.0390^{* * *} \\
(7.88)\end{array}$ & $\begin{array}{c}0.0408^{* * *} \\
(8.19)\end{array}$ & $\begin{array}{l}0.0277^{* * *} \\
(6.29)\end{array}$ & $\begin{array}{c}0.0330^{* * *} \\
(6.80)\end{array}$ & $\begin{array}{c}0.0138^{* * *} \\
(3.98)\end{array}$ & $\begin{array}{c}0.00812^{* * *} \\
(3.56)\end{array}$ \\
\hline Householdhead's schooling years & $\begin{array}{c}-0.00693^{* * *} \\
(-9.18)\end{array}$ & $\begin{array}{c}-0.00478^{* * *} \\
(-7.70)\end{array}$ & $\begin{array}{c}-0.00399^{* * *} \\
(-6.26)\end{array}$ & $\begin{array}{c}-0.00328^{* * *} \\
(-6.16)\end{array}$ & $\begin{array}{c}-0.00207^{* * *} \\
(-3.98)\end{array}$ & $\begin{array}{c}-0.00107^{* * *} \\
(-3.34)\end{array}$ \\
\hline Household size & $\begin{array}{c}0.00437^{* * *} \\
(4.06)\end{array}$ & $\begin{array}{c}0.00410^{* * *} \\
(3.87)\end{array}$ & $\begin{array}{c}0.00282^{* * *} \\
(3.34)\end{array}$ & $\begin{array}{c}0.00249^{* * *} \\
(3.60)\end{array}$ & $\begin{array}{c}0.00141^{*} \\
(2.42)\end{array}$ & $\begin{array}{c}0.00108^{* *} \\
(2.89)\end{array}$ \\
\hline logpchhy & $\begin{array}{c}-0.0205^{* * *} \\
(-5.46)\end{array}$ & $\begin{array}{c}-0.0285^{* * *} \\
(-6.64)\end{array}$ & $\begin{array}{c}-0.0192^{* * *} \\
(-5.77)\end{array}$ & $\begin{array}{c}-0.0118^{* * *} \\
(-4.41)\end{array}$ & $\begin{array}{c}-0.00646^{* * *} \\
(-3.35)\end{array}$ & $\begin{array}{c}-0.00456^{* * *} \\
(-3.37)\end{array}$ \\
\hline $\begin{array}{l}\text { 3__Attending_school_and_working } \\
\text { male }\end{array}$ & $\begin{array}{c}0.0159^{* * *} \\
(4.00)\end{array}$ & $\begin{array}{c}0.0180^{* * *} \\
(3.88)\end{array}$ & $\begin{array}{l}0.0120^{* * *} \\
(3.75)\end{array}$ & $\begin{array}{l}0.0173^{* * *} \\
(4.18)\end{array}$ & $\begin{array}{c}0.00567 \\
(1.66)\end{array}$ & $\begin{array}{c}0.00154^{*} \\
(2.50)\end{array}$ \\
\hline Householdhead's schooling years & $\begin{array}{c}-0.000771 \\
(-1.28)\end{array}$ & $\begin{array}{c}-0.000697 \\
(-1.07)\end{array}$ & $\begin{array}{c}-0.000205 \\
(-0.51)\end{array}$ & $\begin{array}{l}-0.0000254 \\
(-0.04)\end{array}$ & $\begin{array}{c}-0.000606 \\
(-1.18)\end{array}$ & $\begin{array}{l}0.0000306 \\
(0.33)\end{array}$ \\
\hline Household size & $\begin{array}{c}0.00206^{*} \\
(1.97)\end{array}$ & $\begin{array}{c}0.00399^{* *} \\
(2.94)\end{array}$ & $\begin{array}{c}0.00139 \\
(1.46)\end{array}$ & $\begin{array}{c}0.00207^{*} \\
(2.22)\end{array}$ & $\begin{array}{c}0.000517 \\
(0.67)\end{array}$ & $\begin{array}{c}-0.0000231 \\
(-0.18)\end{array}$ \\
\hline logpchhy & $\begin{array}{c}-0.0152^{* * *} \\
(-4.39)\end{array}$ & $\begin{array}{c}-0.0176^{* * *} \\
(-4.14)\end{array}$ & $\begin{array}{c}-0.00742^{* *} \\
(-2.96)\end{array}$ & $\begin{array}{c}-0.00792^{* *} \\
(-3.17)\end{array}$ & $\begin{array}{c}-0.00993^{* * *} \\
(-4.47)\end{array}$ & $\begin{array}{c}-0.00142^{* * *} \\
(-4.01)\end{array}$ \\
\hline $\begin{array}{l}\text { 4__Unemployed } \\
\text { male }\end{array}$ & $\begin{array}{c}0.000706^{* * *} \\
(3.46)\end{array}$ & $\begin{array}{c}0.0152^{* * *} \\
(4.73)\end{array}$ & $\begin{array}{c}0.0130^{* * *} \\
(3.66)\end{array}$ & $\begin{array}{c}0.000159^{* * *} \\
(3.32)\end{array}$ & $\begin{array}{c}0.00730^{* *} \\
(2.93)\end{array}$ & $\begin{array}{c}0.00143^{* * *} \\
(3.43)\end{array}$ \\
\hline Householdhead's schooling years & $-0.000138^{* * *}$ & $\begin{array}{c}-0.00136^{* * *} \\
(-3.45)\end{array}$ & $\begin{array}{c}-0.00333^{* * *} \\
(-5.59)\end{array}$ & $-0.0000282^{* * *}$ & $\begin{array}{c}-0.00139^{* * *} \\
(-3.49)\end{array}$ & $\begin{array}{c}-0.000138^{* *} \\
(-2.76)\end{array}$ \\
\hline Household size & $\begin{array}{c}0.000191^{* * *} \\
(4.04)\end{array}$ & $\begin{array}{c}0.00216^{* *} \\
(3.11)\end{array}$ & $\begin{array}{c}0.00320^{* * *} \\
(3.99)\end{array}$ & $\begin{array}{c}0.0000212^{*} \\
(2.09)\end{array}$ & $\begin{array}{c}0.00100 \\
(1.93)\end{array}$ & $\begin{array}{c}0.000194^{* *} \\
(2.90)\end{array}$ \\
\hline logpchhy & $\begin{array}{c}-0.000666^{* *} \\
(-3.16)\end{array}$ & $\begin{array}{c}-0.0146^{* * *} \\
(-5.41)\end{array}$ & $\begin{array}{c}-0.0192^{* * *} \\
(-5.78)\end{array}$ & $\begin{array}{c}-0.000139^{* * *} \\
(-5.02)\end{array}$ & $\begin{array}{c}-0.00612^{* *} \\
(-3.20)\end{array}$ & $\begin{array}{c}-0.000758^{* * *} \\
(-3.43)\end{array}$ \\
\hline $\begin{array}{l}\text { 5_Inactive } \\
\text { male }\end{array}$ & $\begin{array}{c}-0.0336^{* * *} \\
(-5.05)\end{array}$ & $\begin{array}{c}-0.0312^{* * *} \\
(-5.42)\end{array}$ & $\begin{array}{c}-0.0279^{* * *} \\
(-4.40)\end{array}$ & $\begin{array}{c}-0.0199^{* *} \\
(-3.23)\end{array}$ & $\begin{array}{c}-0.0113^{* *} \\
(-2.68)\end{array}$ & $\begin{array}{c}-0.0100^{*} \\
(-2.28)\end{array}$ \\
\hline Householdhead's schooling years & $\begin{array}{c}-0.00991^{* * *} \\
(-9.38)\end{array}$ & $\begin{array}{c}-0.00770^{* * *} \\
(-8.91)\end{array}$ & $\begin{array}{c}-0.00925^{* * *} \\
(-9.67)\end{array}$ & $\begin{array}{c}-0.00833^{* * *} \\
(-8.67)\end{array}$ & $\begin{array}{c}-0.00340^{* * *} \\
(-5.28)\end{array}$ & $\begin{array}{c}-0.00448^{* * *} \\
(-5.43)\end{array}$ \\
\hline Household size & $\begin{array}{c}0.00591^{* * *} \\
(3.70)\end{array}$ & $\begin{array}{c}0.00714^{* * *} \\
(5.33)\end{array}$ & $\begin{array}{c}0.00633^{* * *} \\
(4.19)\end{array}$ & $\begin{array}{c}0.00508^{* * *} \\
(3.37)\end{array}$ & $\begin{array}{c}0.00186 \\
(1.79)\end{array}$ & $\begin{array}{c}0.00216 \\
(1.86)\end{array}$ \\
\hline logpchhy & $\begin{array}{c}-0.0197^{* *} \\
(-2.90)\end{array}$ & $\begin{array}{c}-0.0282^{* * *} \\
(-5.26)\end{array}$ & $\begin{array}{c}-0.0296^{* * *} \\
(-5.55)\end{array}$ & $\begin{array}{c}-0.0128^{* *} \\
(-2.77)\end{array}$ & $\begin{array}{c}-0.0124^{* * *} \\
(-3.92)\end{array}$ & $\begin{array}{c}-0.0117^{* * *} \\
(-3.31)\end{array}$ \\
\hline Urban area $\mathrm{FE}$ & yes & yes & yes & yes & yes & yes \\
\hline Age dummies & yes & yes & yes & yes & yes & yes \\
\hline Observations & 5,456 & 6,059 & 5,609 & 4,918 & 4,219 & 3,865 \\
\hline $\begin{array}{l}\text { Pseudo }-R^{2} \\
\text { p-value }\end{array}$ & $\begin{array}{l}0.193 \\
0.000\end{array}$ & $\begin{array}{l}0.182 \\
0.000\end{array}$ & $\begin{array}{l}0.188 \\
0.000\end{array}$ & $\begin{array}{l}0.200 \\
0.000\end{array}$ & $\begin{array}{l}0.204 \\
0.000\end{array}$ & $\begin{array}{l}0.211 \\
0.000\end{array}$ \\
\hline
\end{tabular}

Note 1: Estimates based on a MNL where base category (=5) is "inactive" I report marginal effects based on logit coefficients for each independent variable pertaining to the probability of entering each of the 5 activities. The Hausman-test indicates that the specification of school-employment choices above estimated does not violate the IIA assumption.

Table 5: Marginal effects, School-employment choices

\begin{tabular}{l|cccccc} 
& \multicolumn{5}{|c}{ Marginal effects after mlogit, \% } \\
\hline \hline Attending school only & 0.874 & 0.855 & 0.867 & 0.901 & 0.929 & 0.959 \\
Working only & 0.038 & 0.039 & 0.030 & 0.023 & 0.014 & 0.007 \\
Attending school and working & 0.021 & 0.030 & 0.014 & 0.021 & 0.017 & 0.002 \\
Unemployed & 0.001 & 0.019 & 0.027 & 0.000 & 0.011 & 0.002 \\
Inactive & 0.065 & 0.056 & 0.062 & 0.056 & 0.028 & 0.031 \\
\hline Note 1: Estimates based on the MNL from Table|4
\end{tabular}


Table 6: Marginal effects School-Employment choice and local labor markets. Pooled data, 1992-2002.

\begin{tabular}{|c|c|c|c|c|c|}
\hline & $(1)$ & $(2)$ & $(3)$ & $(4)$ & $(5)$ \\
\hline $\begin{array}{l}\text { 1__Attending_school_only } \\
\text { male }\end{array}$ & $\begin{array}{c}-0.0273^{* * *} \\
(-8.75)\end{array}$ & $\begin{array}{c}-0.0272^{* * *} \\
(-8.76)\end{array}$ & $\begin{array}{c}-0.0293^{* * *} \\
(-7.64)\end{array}$ & $\begin{array}{c}-0.0410^{* * *} \\
(-9.12)\end{array}$ & $\begin{array}{c}-0.0429^{* * *} \\
(-8.34)\end{array}$ \\
\hline Householdhead's schooling years & $\begin{array}{c}0.0142^{* * *} \\
(13.91)\end{array}$ & $\begin{array}{c}0.0141^{* * *} \\
(14.00)\end{array}$ & $\begin{array}{c}0.0192^{* * * *} \\
(17.17)\end{array}$ & $\begin{array}{c}0.0186^{* * *} \\
(12.85)\end{array}$ & $\begin{array}{c}0.0249^{* * *} \\
(15.64)\end{array}$ \\
\hline logpchhy & $\begin{array}{l}0.0589^{* * *} \\
(8.92)\end{array}$ & $\begin{array}{l}0.0595^{* * *} \\
(9.54)\end{array}$ & & $\begin{array}{c}0.0777^{* * *} \\
(8.90)\end{array}$ & \\
\hline logpchhy $\mathrm{X}$ crisis year & $\begin{array}{c}-0.00233 \\
(-0.48)\end{array}$ & $\begin{array}{c}-0.000582 \\
(-0.13)\end{array}$ & & $\begin{array}{c}-0.00000701 \\
(-0.00)\end{array}$ & \\
\hline Crisis year & $\begin{array}{c}0.0105 \\
(0.38)\end{array}$ & $\begin{array}{c}-0.00274 \\
(-0.10)\end{array}$ & $\begin{array}{c}-0.0135 \\
(-0.70)\end{array}$ & $\begin{array}{c}-0.0000252 \\
(-0.00)\end{array}$ & $\begin{array}{c}-0.0589 \\
(-0.52)\end{array}$ \\
\hline trend & $\begin{array}{c}0.0123^{* * *} \\
(6.18)\end{array}$ & $\begin{array}{c}0.0105^{* * *} \\
(5.66)\end{array}$ & $\begin{array}{c}0.00876^{* * *} \\
(4.61)\end{array}$ & $\begin{array}{c}0.0151^{* * * *} \\
(6.51)\end{array}$ & $\begin{array}{c}0.0110^{* * *} \\
(4.09)\end{array}$ \\
\hline Log wage (urban area) & & $\begin{array}{c}-0.0585^{*} \\
(-2.37)\end{array}$ & $\begin{array}{c}-0.01911^{*} \\
(-2.69)\end{array}$ & & \\
\hline Log wage (urban area) $\mathrm{X}$ crisis & & $\begin{array}{c}0.00347^{*} \\
(3.15)\end{array}$ & $\begin{array}{c}0.0151 \\
(2.69)\end{array}$ & & \\
\hline Job rate(urban area) & & & & $\begin{array}{c}-0.00178^{*} \\
(-2.32)\end{array}$ & $\begin{array}{c}-0.00194 \\
(-1.89)\end{array}$ \\
\hline Job rate(urban area) $\mathrm{X}$ crisis & & & & $\begin{array}{c}-0.00180 \\
(-1.08)\end{array}$ & $\begin{array}{c}-0.000311 \\
(-0.22)\end{array}$ \\
\hline $\begin{array}{l}\text { 2_-Working_only } \\
\text { male }\end{array}$ & $\begin{array}{c}0.0276^{* * *} \\
(23.94)\end{array}$ & $\begin{array}{c}0.0275^{* * *} \\
(24.05)\end{array}$ & $\begin{array}{c}0.0299^{* * *} \\
(22.88)\end{array}$ & $\begin{array}{c}0.0422^{* * *} \\
(18.97)\end{array}$ & $\begin{array}{c}0.0448^{* * *} \\
(18.16)\end{array}$ \\
\hline Householdhead's schooling years & $\begin{array}{c}-0.00372^{* * *} \\
(-13.92)\end{array}$ & $\begin{array}{c}-0.00369^{* * *} \\
(-14.05)\end{array}$ & $\begin{array}{c}-0.00521^{* * *} \\
(-15.83)\end{array}$ & $\begin{array}{c}-0.00553^{* * *} \\
(-12.29)\end{array}$ & $\begin{array}{c}-0.00760^{* * *} \\
(-13.69)\end{array}$ \\
\hline logpchhy & $\begin{array}{c}-0.0157^{* * * *} \\
(-7.90)\end{array}$ & $\begin{array}{c}-0.0157^{* * *} \\
(-8.38)\end{array}$ & & $\begin{array}{c}-0.0231^{* * * *} \\
(-7.66)\end{array}$ & \\
\hline logpchhy $\mathrm{X}$ crisis year & $\begin{array}{l}0.00225 \\
(1.87)\end{array}$ & $\begin{array}{c}0.000821 \\
(0.57)\end{array}$ & & $\begin{array}{c}0.000677 \\
(0.40)\end{array}$ & \\
\hline Crisis year & $\begin{array}{c}-0.0115^{*} \\
(-2.41)\end{array}$ & $\begin{array}{c}-0.00866^{*} \\
(-2.06)\end{array}$ & $\begin{array}{c}-0.00504 \\
(-1.14)\end{array}$ & $\begin{array}{l}-0.0421^{* * *} \\
(-4.09)\end{array}$ & $\begin{array}{c}-0.0327^{*} \\
(-2.43)\end{array}$ \\
\hline trend & $\begin{array}{c}-0.00435^{* * *} \\
(-7.35)\end{array}$ & $\begin{array}{c}-0.00381^{* * *} \\
(-5.99)\end{array}$ & $\begin{array}{c}-0.00350^{* * *} \\
(-5.29)\end{array}$ & $\begin{array}{c}-0.00582^{* * *} \\
(-9.55)\end{array}$ & $\begin{array}{c}-0.00475^{* * *} \\
(-6.70)\end{array}$ \\
\hline Log wage (urban area) & & $\begin{array}{c}0.0178^{* * *} \\
(3.41)\end{array}$ & $\begin{array}{c}0.00782 \\
(1.37)\end{array}$ & & \\
\hline Log wage (urban area) $\mathrm{X}$ crisis & & $\begin{array}{c}0.00603 \\
(0.80)\end{array}$ & $\begin{array}{c}0.00574 \\
(0.92)\end{array}$ & & \\
\hline Job rate(urban area) & & & & $\begin{array}{c}0.00175^{*} \\
(1.99)\end{array}$ & $\begin{array}{c}0.00200^{* *} \\
(2.63)\end{array}$ \\
\hline Job rate(urban area) $\mathrm{X}$ crisis & & & & $\begin{array}{c}0.00129^{* *} \\
(2.64)\end{array}$ & $\begin{array}{c}0.000941 \\
(1.94)\end{array}$ \\
\hline $\begin{array}{l}\text { 3__Attending_school_and_working } \\
\text { male }\end{array}$ & $\begin{array}{c}0.0108^{* * *} \\
(13.05)\end{array}$ & $\begin{array}{c}0.0108^{* * *} \\
(13.22)\end{array}$ & $\begin{array}{c}0.0113^{* * *} \\
(12.17)\end{array}$ & $\begin{array}{c}0.0129^{* * *} \\
(12.91)\end{array}$ & $\begin{array}{c}0.0134^{* * *} \\
(11.87)\end{array}$ \\
\hline Householdhead's schooling years & $\begin{array}{c}-0.000580^{* * *} \\
(-3.30)\end{array}$ & $\begin{array}{c}-0.000567^{* *} \\
(-3.22)\end{array}$ & $\begin{array}{c}-0.00142^{* * *} \\
(-6.63)\end{array}$ & $\begin{array}{c}-0.000477^{*} \\
(-2.43)\end{array}$ & $\begin{array}{c}-0.00145^{* * *} \\
(-6.08)\end{array}$ \\
\hline $\log p c h h y$ & $\begin{array}{c}-0.0107^{* * *} \\
(-8.06)\end{array}$ & $\begin{array}{c}-0.0109^{* * *} \\
(-8.34)\end{array}$ & & $\begin{array}{c}-0.0127^{* * * *} \\
(-8.32)\end{array}$ & \\
\hline logpchhy $\mathrm{X}$ crisis year & $\begin{array}{c}0.00101 \\
(0.65)\end{array}$ & $\begin{array}{c}0.000911 \\
(0.55)\end{array}$ & & $\begin{array}{c}0.000193 \\
(0.09)\end{array}$ & \\
\hline Crisis year & $\begin{array}{c}-0.00923 \\
(-1.65)\end{array}$ & $\begin{array}{c}-0.00579 \\
(-0.84)\end{array}$ & $\begin{array}{c}-0.000582 \\
(-0.16)\end{array}$ & $\begin{array}{c}-0.00836 \\
(-0.54)\end{array}$ & $\begin{array}{c}0.00428 \\
(0.19)\end{array}$ \\
\hline trend & $\begin{array}{c}-0.00171^{* * *} \\
(-7.65)\end{array}$ & $\begin{array}{c}-0.00123^{* *} \\
(-3.21)\end{array}$ & $\begin{array}{c}-0.000854^{*} \\
(-2.37)\end{array}$ & $\begin{array}{c}-0.00146^{* * *} \\
(-3.96)\end{array}$ & $\begin{array}{c}-0.000758^{*} \\
(-1.99)\end{array}$ \\
\hline Log wage (urban area) & & $\begin{array}{c}0.0162 \\
(1.71)\end{array}$ & $\begin{array}{c}0.0103 \\
(1.12)\end{array}$ & & \\
\hline Log wage (urban area) $\mathrm{X}$ crisis & & $\begin{array}{c}-0.00399 \\
(-1.00)\end{array}$ & $\begin{array}{c}-0.00579 \\
(-1.23)\end{array}$ & & \\
\hline Job rate(urban area) & & & & $\begin{array}{c}0.00163^{* *} \\
(2.97)\end{array}$ & $\begin{array}{c}0.00165^{* *} \\
(2.94)\end{array}$ \\
\hline Job rate(urban area) $\mathrm{X}$ crisis & & & & $\begin{array}{c}0.000115 \\
(0.29)\end{array}$ & $\begin{array}{c}-0.000148 \\
(-0.39) \\
\end{array}$ \\
\hline $\begin{array}{l}\text { 4_-Unemployed } \\
\text { male }\end{array}$ & $\begin{array}{c}0.0116^{* * *} \\
(11.31)\end{array}$ & $\begin{array}{c}0.0115^{* * *} \\
(11.11)\end{array}$ & $\begin{array}{c}0.0118^{* * *} \\
(10.09)\end{array}$ & $\begin{array}{c}0.0171^{* * *} \\
(12.83)\end{array}$ & $\begin{array}{c}0.0174^{* * *} \\
(11.35)\end{array}$ \\
\hline Householdhead's schooling years & $\begin{array}{c}-0.00241^{* * *} \\
(-9.84)\end{array}$ & $\begin{array}{c}-0.00238^{* * *} \\
(-9.53)\end{array}$ & $\begin{array}{c}-0.00341^{* * *} \\
(-10.69)\end{array}$ & $\begin{array}{c}-0.00351^{* * * *} \\
(-9.25)\end{array}$ & $\begin{array}{c}-0.00499^{* * *} \\
(-10.79)\end{array}$ \\
\hline logpchhy & $\begin{array}{c}-0.0127^{* * *} \\
(-8.62)\end{array}$ & $\begin{array}{c}-0.0128^{* * *} \\
(-9.06)\end{array}$ & & $\begin{array}{c}-0.0189^{* * *} \\
(-9.18)\end{array}$ & \\
\hline logpchhy $\mathrm{X}$ crisis year & $\begin{array}{c}0.00180 \\
(1.55)\end{array}$ & $\begin{array}{c}0.000477 \\
(0.33)\end{array}$ & & $\begin{array}{c}0.00250 \\
(1.21)\end{array}$ & \\
\hline Crisis year & $\begin{array}{c}-0.00723 \\
(-1.63)\end{array}$ & $\begin{array}{c}-0.00342 \\
(-0.66)\end{array}$ & $\begin{array}{c}0.00475 \\
(0.60)\end{array}$ & $\begin{array}{c}-0.0496^{* * *} \\
(-4.12)\end{array}$ & $\begin{array}{c}-0.0407^{* *} \\
(-2.69)\end{array}$ \\
\hline trend & $\begin{array}{c}-0.00182^{* * *} \\
(-4.36)\end{array}$ & $\begin{array}{c}-0.00108^{*} \\
(-2.35)\end{array}$ & $\begin{array}{c}-0.000549 \\
(-1.19)\end{array}$ & $\begin{array}{c}-0.00338^{* * *} \\
(-4.09)\end{array}$ & $\begin{array}{c}-0.00222^{*} \\
(-2.45)\end{array}$ \\
\hline Log wage (urban area) & & $\begin{array}{c}0.0219^{*} \\
(2.21)\end{array}$ & $\begin{array}{c}0.0148 \\
(1.25)\end{array}$ & & \\
\hline Log wage (urban area) $\mathrm{X}$ crisis & & $\begin{array}{c}0.00493 \\
(0.56)\end{array}$ & $\begin{array}{c}-0.000411 \\
(-0.05)\end{array}$ & & \\
\hline Job rate(urban area) & & & & $\begin{array}{c}-0.00277^{* * *} \\
(-3.37)\end{array}$ & $\begin{array}{c}-0.00283^{* * *} \\
(-3.53)\end{array}$ \\
\hline Job rate(urban area) $\mathrm{X}$ crisis & & 38 & & $\begin{array}{c}0.00145^{*} \\
(1.99)\end{array}$ & $\begin{array}{c}0.00118 \\
(1.62)\end{array}$ \\
\hline Urban area $\mathrm{FE}$ & yes & yes & yes & yes & yes \\
\hline Age dummies and $F E L$ dummy & yes & yes & yes & yes & yes \\
\hline Observations & 58254 & 58254 & 61517 & 48435 & 51155 \\
\hline
\end{tabular}

See notes Table 4. Robust Huber-White standard errors are clustered at the urban-area level. Effects on the inactive not reported but available upon request. 
Table 7: Marginal effects, School-Employment choice, Jobs and the Federal Education Law, 13-18 year olds

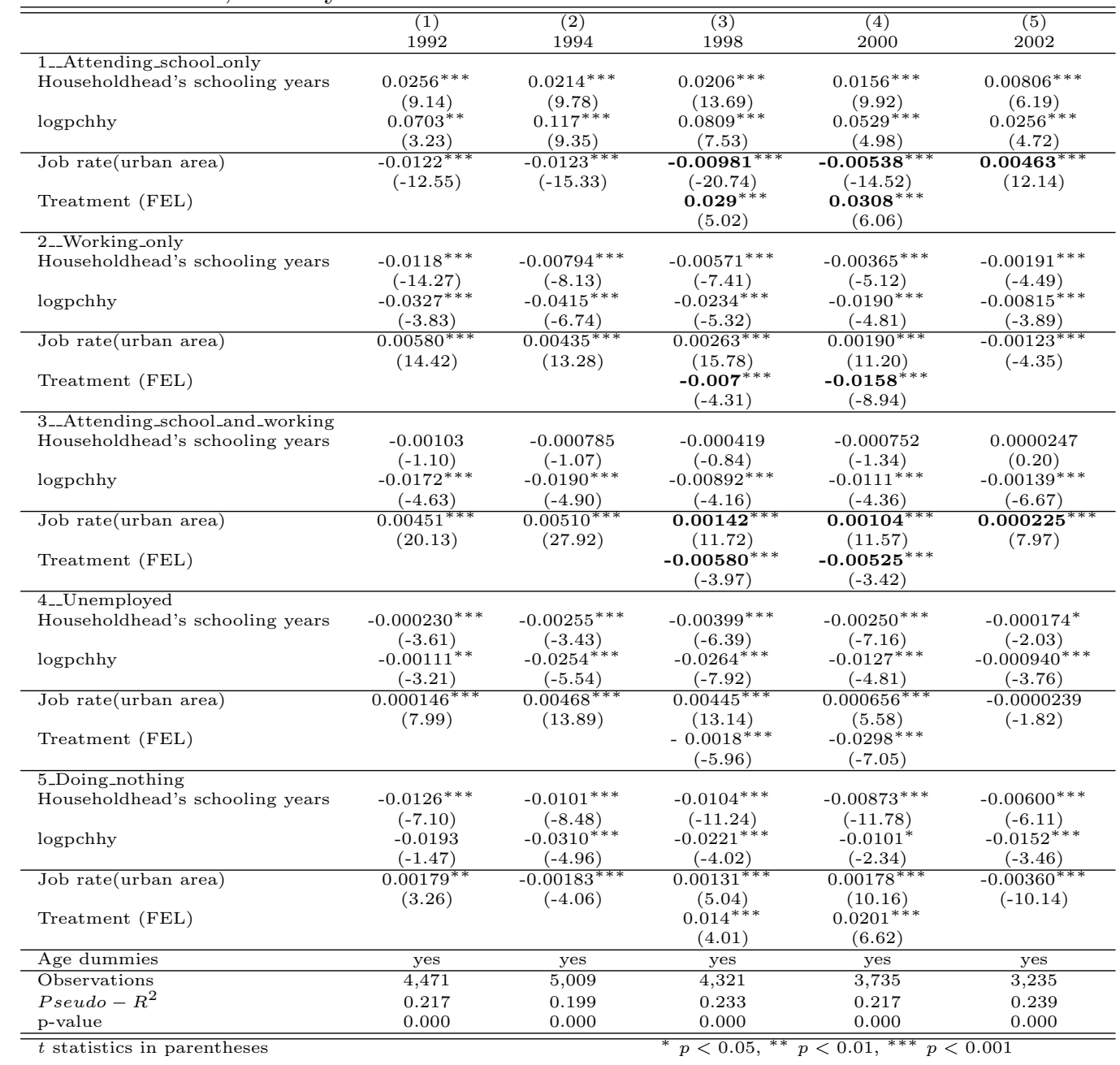

See Notes Table 4 Robust Huber-White standard errors in parenthesis clustered at urban area level. 
Table 8: Marginal effects, School-Employment choice, Unemployment and FEL $13-18$ year olds

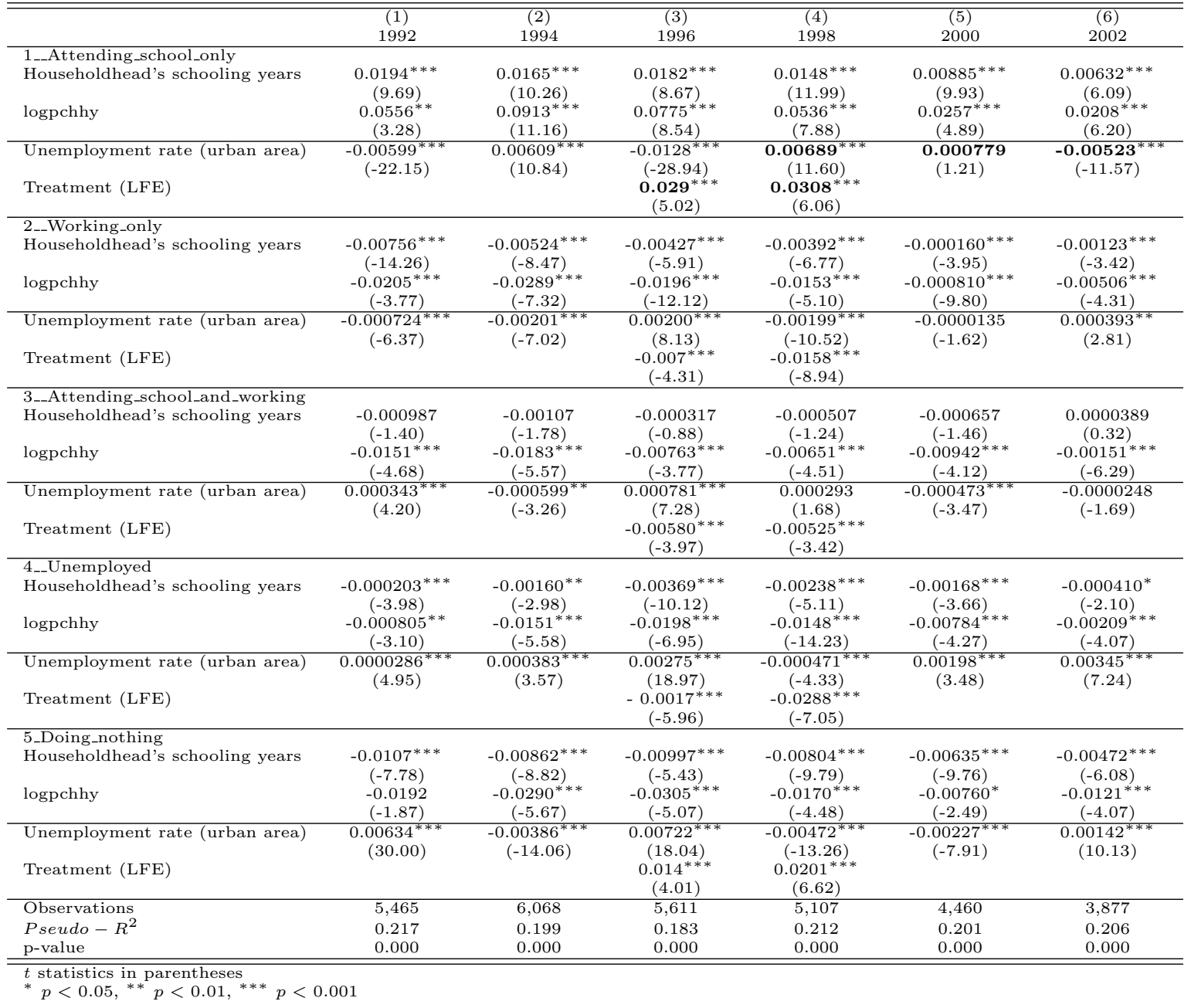

See Notes Table 4 . Robust Huber-White standard errors in parenthesis clustered at urban area level. 
Table 9: Marginal effects for jointly determined outcomes

\begin{tabular}{|c|c|c|}
\hline & Prob. in school only & Change from baseline \\
\hline baseline 1992 & 0.850 & \\
\hline $10 \%$ decrease in job rate & 0.972 & 0.122 \\
\hline baseline 2000 & 0.900 & \\
\hline $10 \%$ decrease in job rate & 0.954 & 0.054 \\
\hline Federal Education Law & 0.931 & 0.030 \\
\hline baseline 2002 & 0.948 & \\
\hline \multirow[t]{2}{*}{$10 \%$ decrease in job rate } & 0.902 & -0.046 \\
\hline & Prob. works only & Change from baseline \\
\hline baseline 1992 & $\begin{array}{ll}0.038 \\
\end{array}$ & \\
\hline $10 \%$ increase in job rate & 0.096 & 0.058 \\
\hline baseline 2000 & 0.023 & \\
\hline $10 \%$ increase in job rate & 0.049 & 0.026 \\
\hline Federal Education Law & 0.007 & -0.016 \\
\hline baseline 2002 & 0.007 & \\
\hline \multirow{2}{*}{$10 \%$ increase in job rate } & -0.005 & -0.012 \\
\hline & Prob. in school and works & Change from baseline \\
\hline baseline 1992 & 0.021 & \\
\hline $10 \%$ increase in job rate & 0.067 & 0.045 \\
\hline baseline 2000 & 0.021 & \\
\hline $10 \%$ increase in job rate & 0.031 & 0.010 \\
\hline Federal Education Law & 0.016 & 0.005 \\
\hline baseline 2002 & 0.002 & \\
\hline $10 \%$ increase in job rate & 0.004 & 0.002 \\
\hline
\end{tabular}

Note 1: $\overline{\overline{\text { Estimates based on a MNL where base category (=5) is "inactive" I report marginal }}}$ effects based on logit coefficients for each independent variable pertaining to the probability of entering each of the 5 activities. Note 2: Age, gender, household head's schooling years, household size and per capita household income controls are included and significant at $99 \%$ level. Note 3: Baselines are evaluated using all variables kept at their means, including urban area job rates. Note that I evaluate the scenario of decreasing job rates for the probability of being in school only, and of increasing job rates for the other two probabilities, which provides a more intuitive final result. 


\section{References}

Altimir, O., And L. Beccaria (2001): "El persistente deterioro de la distribución del ingreso en la Argentina," Desarrollo Económico, 40(160), 589-61.

AndREOni, J. (1989): "Giving with impure altruism; applications to charity and Ricardian equivalence," Journal of Political Economy, 97(6), 1447-58.

Basu, K., and P. H. Van (1998): "The Economics of Child Labor," The American Economic Review, 88(3), 412-427.

Becker, G. (1964): Human Capital: A Theoretical and Empirical Analysis with Special Reference to Education. University of Chicago Press.

Beegle, K., R. H. Dehejia, and R. Gatti (2005a): "Child Labour, Crop Shocks and Credit Constraints," CEPR Discussion Papers 4881.

(2005b): "Why Should We Care about Child Labor? The Education, Labor Market, and Health Consequences of Child Labor," World Bank Policy Research Working Paper Report 3479.

Behrman, J. R., N. Birdsall, and M. Szekely (2000): "Intergenerational Mobility in Latin America: Deeper Markets and Better Schools Make a Difference," in New markets, new opportunities? Economic and social mobility in a changing world, ed. by C. Birdsall, Nancy; Graham, pp. 135-67. Carnegie Endowment for International Peace Brookings Institution Press, Washington, D.C.

Behrman, J. R., and J. C. Knowles (1999): "Household Income and Child Schooling in Vietnam," World Bank Economic Review, 13(2), 21156 .

Cameron, S. V., and J. J. Heckman (1998): "Life Cycle Schooling and Dynamic Selection Bias: Models and Evidence for Five Cohorts of American Males," Journal of Political Economy, 106(2), 262-333.

Card, D., and A. B. Krueger (1994): "Minimum Wages and Employment: A Case Study of the Fast-Food Industry in New Jersey and Pennsylvania," American Economic Review, 84(4), 772-93.

Crosta, F. L. (2007): "Exploring the effects of the school levels reform on access and its quality: The Education Federal Law of Argentina," Well being and social policy, 3(1), 97-122.

De Ferranti, D., G. E. Perry, S. G. Indermit, and L. Serven (2000): Securing Our Future in a Global Economy. World Bank Latin American and Caribbean Studies Series, Washington D.C. 
De Janvry, A., F. Finan, E. Sadoulet, and R. Vakis (2006): "Can Conditional Cash Transfer Programs Serve as Safety Nets in Keeping Children at School and from Working When Exposed to Shocks?," Journal of Development Economics, 79(2), 349373.

Duflo, E. (2001): "Schooling And Labor Market Consequences Of School Construction In Indonesia: Evidence From An Unusual Policy Experiment," American Economic Review, 91(4), 795-813.

Duryea, S., And M. Arends Kuenning (2003): "School Attendance, Child Labor and Local Labor Market Fluctuations in Urban Brazil," World Development, 31(7), 1165-1178.

Duryea, S., D. Lam, and D. Levison (2007): "Effects of Economic Shocks on Children's Employment and Schooling in Brazil," Journal of Development Economics, 84(1), 188-214.

Fiszbein, A., H. A. Patrinos, and P. I. Giovagnoli (2005): "Estimating the returns to education in Argentina: 1992-2002," Technical report. The World Bank, Policy Research Working Paper Series: 3715.

Galiani, S., and E. Schargrodsky (2001): "Evaluating the Impact of School Decentralization on Education Quality," Unpublished manuscript.

Galor, O., AND J. ZeIRA (1993): "Income distribution and macroeconomics," Review of Economics Studies, 60, 35-52.

Goldin, C. (1999): "Egalitarianism and the Returns to Education during the Great Transformation of American Education," Journal of Political Economy, 107(4), S65-S94.

Hausman, J. (1978): "Specifications tests in econometrics," Econometrica, $46,1251-1271$.

Hausman, J., and D. MCFadden (1984): "Specifications tests in econometrics," Econometrica, 52, 1219-1240.

Hausmann, R., and M. Szekely (2001): "Population Matters: Inequality and the Family in Latin America," in Demographic Change, Economic Growth, and Poverty in the Developing World, ed. by A. C. S. S. W. Birdsall, Nancy.; Kelley, pp. 260-95. Oxford University Press, Oxford and New York.

JACOBY, H. (1994): "Borrowing contraints and progress through school: Evidence from Peru," Review of Economics and Statistics, 76(1), 151160. 
Jacoby, H., and E. Skoufias (1997): "Risk, Financial Markets and Human Capital in a Developing Country," Review of Economic Studies, 64(3), 311-335.

Jensen, R. (2000): "Agricultural Volatility and Investments in Children," American Economic Review, 90(2), 399-404.

Long, S. (1997): Regression Models for Categorical and Limited Dependent Variables. Sage publication, Thousand Oaks, London.

Lopez Boo, F. (2008): "The evolution of returns to education: Argentina 1992-2003," DPhil thesis Chapter.

McKenzie, D. (2003): "Aggregate Shocks and Labor Market Responses: Evidence from Argentinas Financial Crisis," Economic Development and Cultutral Change, 52(4), 719-58.

Parandekar, S., S. Espana, and M. P. Savanti (2003): "The impact of the crisis on the Argentine educational process," World Bank Working Paper Series 03/03 Background paper number 7.

Ravallion, M., and Q. Wodon (2000): "Does Child Labor Displace Schooling? Evidence on Behavioral Responses to an Enrollment Subsidy," The Economic Journal, 110, C158-C175.

Rosen, S. (1977): "Human Capital: A Survey of Empirical Research," in Research in Labor Economics, ed. by R. Ehrenberg, vol. 1. JAI Press, Greenwich Conn.

Rucci, G. (2004): "The Effects of Macroeconomic Shocks on the Well-Being of People in Developing Countries," 2004., Ph.D. University of California Los Angeles.

Schady, N. (2004): "Do macroeconomic crises always slow down human capital accumulation," The World Bank Economic Review, 18(2).

Söderbom, M., W. A. Teal F., and G. Kahyarara (2006): "The Dynamics of Returns to Education in Kenyan and Tanzanian Manufacturing," Oxford Bulletin of Economics and Statistics, 68(3), 261.

Sosa, W., And M. Marchionni (1999): "Household structure, gender, and the economic determinants of school attendance in Argentina," Reunin Anual de la AAEP, Rosario, Unpublished manuscript.

Thomas, D., K. Beegle, E. Frankenberg, B. Sikoki, J. Strauss, And G. Teruel (2004): "Education in a crisis," Journal of Development Economics, 74(1), 53-85. 
WiLlis, R. (1986): "Wage determinants: a survey and reinterpretation of human capital earnings function," in Handbook of labor economics, Chapter 10, ed. by O. Ashenfelter, and R. Layard, vol. 1, pp. 525-602. North Holland Elsevier Science, Amsterdam.

Wooldridge, J. (2002): Econometric Analysis of Cross Section and Panel Data. MIT Press.

Zivot, E., And D. Andrews (1992): "Further evidence on the Great Crash, the oil price shock, and the unit-root hypothesis," Journal of Business and Economic Statistics, 10, 251-70. 